\title{
A Study on Technical Efficiency of Rice Production in The Mekong Delta-Vietnam by Stochastic Frontier Analysis
}

\section{Nguen Thi Minh Hien}

Laboratory of Quantitative Analysis of Agribusiness organization, Division of Industrial Organization of Agribusiness, Department of Agricultural and Resoruce Economics, Graduate School of Bioresoruce adn Bioenvironmental Sciences, Kyushu University

\section{Kawaguchi, Tsunemasa}

Laboratory of Quantitative Analysis of Agribusiness Oragnization, Division of Industrial Organization of Agribusiness, Department of Agricultural and Resource Economics Faculty of Agriculture, Kyushu University

Suzuki, Nobuhi ro

Laboratory of Quantitative Analysis of Agribusiness Oragnization, Division of Industrial Organization of Agribusiness, Department of Agricultural and Resource Economics Faculty of Agriculture, Kyushu University

https://doi.org/10.5109/4553

出版情報：九州大学大学院農学研究院紀要. 48 (1/2)，pp. 325-357，2003-10-01. Faculty of Agriculture, Kyushu University

バージョン：

権利関係 : 


\title{
A Study on Technical Efficiency of Rice Production in The Mekong Delta-Vietnam by Stochastic Frontier Analysis
}

\author{
NGUYEN Thi Minh Hien*, Tsunemasa KAWAGUCHI \\ and Nobuhiro SUZUKI
}

\author{
Laboratory of Quantitative Analysis of Agribusiness Organization, Division of Industrial \\ Organization of Agribusiness, Department of Agricultural and Resource Economics \\ Faculty of Agriculture, Kyushu University, Fukuoka 812-8581, Japan \\ (Received may 23, 2003 and accepted July 15, 2003)
}

\begin{abstract}
The Mekong Delta plays a very important role in the rice production sector of Vietnam. However, income of rice grower in the Mekong Delta and Vietnam as well is still very low. Finding out the way to increase the efficiency of rice production in order to improve income for farmers and to enhance the comparative advantage of Vietnam's rice industry has become the most crucial issue. A stochastic frontier production function incorporating a model for technical inefficiency effects (Battese and Coelli, 1995) is applied to field survey data on 120 paddy farmers of the Mekong Delta.

We could infer that there exists difference in the level of technical efficiency across season and the size of operational holding as well in paddy farming in the Mekong Delta. The mean technical efficiencies of $86.23 \%, 79.55 \%$ and $80.24 \%$ were achieved by paddy farms in winter-spring, spring-summer and summer-autumn, respectively in the Mekong Delta showing the scope for increasing paddy production by $13.8 \%, 20.45 \%$ and $19.76 \%$ with the present technology itself. Regarding to variables affecting stochastic frontier, it was found that quantity of seed, active nitrogen and expense for pesticide had negative impact on the rice yield. On the other hand quantity of active phosphate and potassium and expense for hired machine have positive impact on rice yield. However those inputs were all allocated inefficiently. The technical inefficiency effects in the stochastic models are found to be statistically significant, dummy variables of land size, rice variety use, IPM adoption and sowing technique together with availability of credit are found to have positive impact on technical efficiency. The average yield loss due to technical inefficiency was relatively high with 727.03 and $705.93 \mathrm{~kg}$ per hectare in winter-spring and summer-autumn crops respectively and farmers who operate with farm size of 1-3 hectare could achieve highest efficiency and lowest yield loss. These results may help agricultural policy makers formulate strategies.
\end{abstract}

\section{INTRODUCTION}

The Mekong Delta plays a very important role in Vietnam's overall rice production. Due to the economic reforms and other policies, the agricultural production in the Mekong Delta has significantly improved over the years. Rice production has become a very important income source for farmers in the region, contributing more than $50 \%$ of the total paddy production of the country and nearly accounting for $90 \%$ of export rice

\footnotetext{
* Laboratory of Quantitative Analysis of Agribusiness Organization, Division of Industrial Organization of Agribusiness, Department of Agricultural and Resource Economics, Graduate School of Bioresource and Bioenvironmental Sciences, Kyushu University

+ Corresponding author (E-mail: nthiminhien@yahoo.com)
} 
volume. Therefore, the development of rice production in the Mekong Delta has been meaningful for attaining the country's food security and for export earnings. As such, finding out a way to improve the efficiency of rice production in order to increase farmers' income and to enhance the comparative advantage of Vietnam's rice industry has become the most crucial issue.

Through the analysis of rice production and marketing of the Mekong Delta, the study attempts to suggest appropriate policy measures to promote and improve the efficiency of rice production in order to raise the living standard of farmers in the region. The specific objectives of the study are as follows: 1) To study and describe the current situation of rice production, 2) To investigate the technical efficiency of rice producers in the Mekong Delta by using the stochastic frontier models 3 ) To provide recommendations for enhancing the economic efficiency of rice production in the Mekong Delta.

The measurement of efficiency is very important because it is a factor for productivity growth. Such a study helps to benefit by determining the extent to which it is possible to raise productivity by improving the neglected resource, i.e. efficiency, with the existing resource base and the available technology.

\section{METHODOLOGY}

\section{Theoretical framework of stochastic frontier analysis Efficiency}

Two types of production efficiency were defined by Farrell (1957): technical efficiency and allocative efficiency. Technical efficiency evaluates the ability to obtain a higher level of output from a given set of inputs, while allocative efficiency measures the extent to which farmers make efficient decisions by using inputs up to level at which marginal contribution to production value equal to the factor cost, assuming no risk.

Technical efficiency is just one component of overall economic efficiency. However, in order to be economically efficient, a farm must be technically efficient. Profit maximization requires a farm to produce the maximum output given a level of inputs employed (i.e. be technically efficient), use the right mix of inputs in light of the relative price of each input (i.e. be input allocatively efficient) and produce the right mix of outputs given
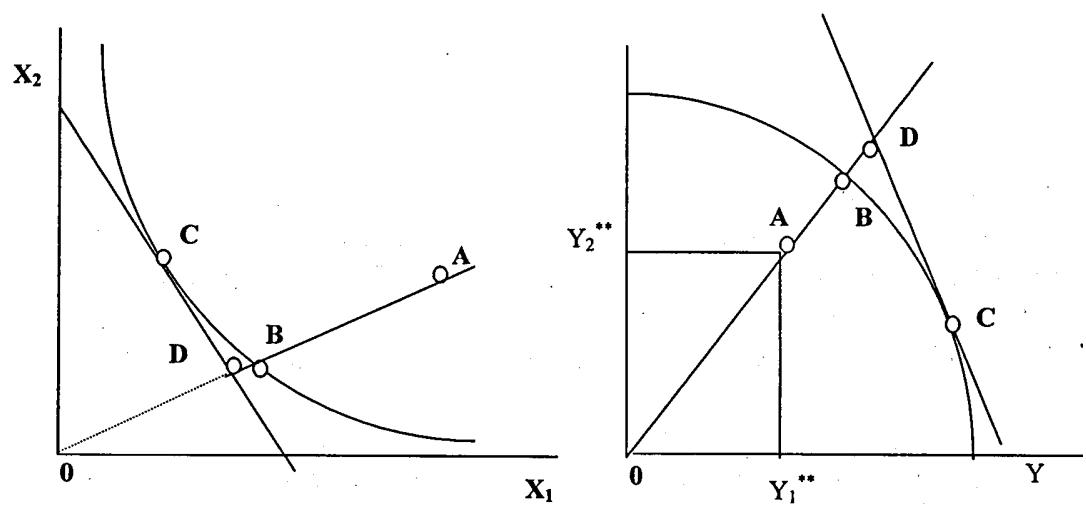

Figure 1. Input (a) and output (b) oriented efficiency measure 
the set of price (i.e. be output allocatively efficient) (Kumbhaker and Lovell 2000).

These concepts can be illustrated graphically using a simple example of a set of two inputs $\left(x_{1}, x_{2}\right)$, and a set of two outputs $\left(y_{1}, y_{2}\right)$ in production process (Figure 1). Efficiency can be considered in terms of the optimal combination of inputs to achieve a given level of output (an input orientation), or the optimal output that could be produced given a set of inputs (an output orientation).

In figure 1 (a), the farm is producing a given level of output by using an input combination defined by point $A$. The same level of output could have been produced by contracting the use of both inputs back to point $B$, which lies on the isoquant associated with the minimum level of inputs required to produce such output. The input-oriented level of technical efficiency $\mathrm{TE}$ is defined by $0 \mathrm{~B} / 0 \mathrm{~A}$. However, the least cost combination of inputs that produces the same level of output is given by point $\mathrm{C}$ where the marginal rate of technical substitution is equal to the input price ratio. To achieve the same level of cost, the input would need to be further contracted to point $\mathrm{D}$. The cost efficiency CE is therefore defined by $0 \mathrm{D} / 0 \mathrm{~A}$. The input allocative efficiency $\mathrm{AE}$ is given by CE/TE or OD/0B (Kumbhaker and Lovell 2000).

Figure 1 (b) illustrates the production possibility frontier for a given set of inputs. If the input employed by the farm were used efficiently, the output of the firm can be expanded to point $B$ instead of point $A$ as present. Here, the output oriented measure of technical efficiency can be illustrated by $0 \mathrm{~A} / 0 \mathrm{~B}$. Although point $\mathrm{B}$ lying in the production possibility frontier indicates the technical efficiency, however higher revenue could be achieved by producing at point $\mathrm{C}$ where the maginal rate of transformation is equal to the price ratio. In this case, more of $y_{1}$ should be introduced and less of $y_{2}$ in order to maximize revenue. To achieve the same level of revenue at point $\mathrm{C}$ while maintaining the same input and output combination, output of the farm would need to be expanded to point $\mathrm{D}$. Hence, the revenue efficiency $\mathrm{RE}$ is given by $0 \mathrm{~A} / 0 \mathrm{D}$. Output allocative efficiency $\mathrm{AE}$ is given by RE/TE or OB/0D (Kumbhaker and Lovell 2000).

\section{Stochastic production frontier}

In simple terms, the stochastic frontier approach amounts to specifying the relationship between output and input levels using two error terms. One error term is the traditional normal error term in which the mean is zero and the variance is constant. The other error term represents technical inefficiency and may be expressed as a half-normal, truncated normal, exponential, or two-parameter gamma distribution. Technical efficiency is subsequently estimated via maximum likelihood of the production function subject to the two error terms.

The stochastic frontier production function was independently proposed by Aigner, Lovell and Schmidt (1977) and Meeusen and Van den Broeck (1977). The original specification involved a production function specified for cross-sectional data, which had an error term with 2 components, one account for random effects and other to account for technical inefficiency. This model can be expressed as follows:

$$
Y_{i}=x_{i} \beta+\varepsilon_{i}=x_{i} \beta+\left(V_{i}-U_{i}\right) \quad i=1 \ldots . . N
$$

Where:

$Y_{i}$ is the production (or the logarithm of the production) of the $\mathrm{i}$-th farm

$X_{i}$ is a $1 \times k$ vector of transformation of input quantities of the $\mathrm{i}$-th farm 
$\beta$ is an vector of unknown parameters

The $V_{i}$ are random variables which are assumed to be independently and identically distributed with $\mathrm{N}\left(0, \sigma_{\mathrm{v}}{ }^{2}\right)$

$\mathrm{U}_{\mathrm{i}}$-non-negative random variables are assumed to account for technical inefficiency in production and are often assumed to be independently and identically distributed non-negative truncation of the $\mathrm{N}\left(\mu, \sigma_{\mathrm{u}}^{2}\right)$ distribution.

Error term $\varepsilon_{i}=v_{i}-u_{i}$ is not symmetric since ui $\geq 0$

The variation parameters of the model are parameterized as

$$
\sigma^{2}=\sigma_{v}^{2}+\sigma_{u}^{2} \text { and } \gamma=\sigma_{u}^{2} /\left(\sigma_{v}^{2}+\sigma_{u}^{2}\right)
$$

The parameter $\gamma$ must be lie between 0 and $1(0 \leq \gamma \leq 1)$

The concept of technical efficiency using stochastic frontier production function is demonstrated in Figure 2. The random error term $\mathrm{v}$ allows frontier output values vary around the deterministic production frontier $Y=f(X)$.

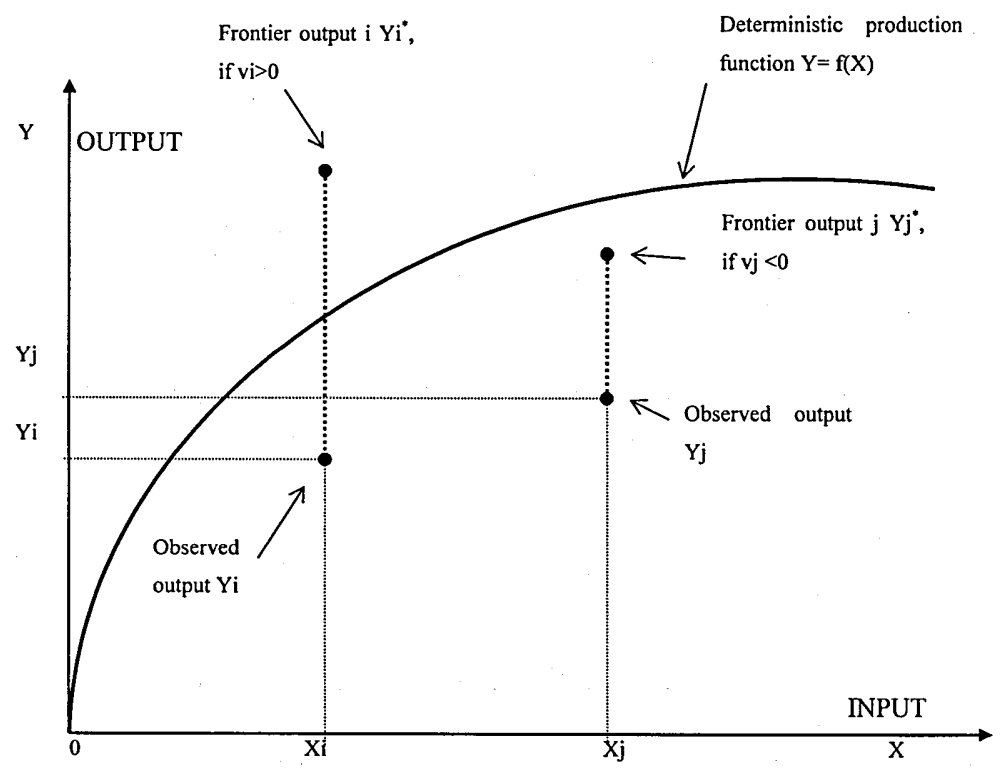

Figure 2. Stochastic frontier production function

\section{Methodology applied in the study \\ Data collection}

Mekong Delta was chosen for conducting research. The study was based on the both secondary and primary data. Secondary data such as data of socio-economic condition, provincial and district data about agricultural and rice production, and policy guideline were obtained from official publication, local offices' reports, or personal interview.

The primary data was collected based on the author's own survey in 2002 in the irri- 
gated lowland rice area in the Mekong Delta. Two provinces, namely Can Tho and Tien Giang province were selected as the study areas because they are two of provinces having large rice cultivating areas. Besides, both provinces supply large commercial rice volume. This situation makes provinces of Tien Giang and Can Tho suitable to study on marketing of rice also.

One hundred and twenty rice farming households were interviewed with classification into 5 groups according to scale of farm: farm size of less than $0.2 \mathrm{ha}$, of $0.2-0.5 \mathrm{ha}$, of $0.5-1$ ha, of 1-3 ha and of more than 3 ha. The numbers of households in each group were reported in the table 1 (hereafter Can Tho and Tien Giang province are abbreviated as CT and TG).

Table 1. Number of surveyed rice growing household by locations and farm size

\begin{tabular}{lrrrrrr}
\hline Farm scale & CT & $\%$ & TG & $\%$ & Total & $\%$ \\
\hline Less than 0.2 ha & 4 & 6.35 & 8 & 14.04 & 12 & 10 \\
$0.2-0.5$ ha & 20 & 31.75 & 10 & 17.54 & 30 & 25 \\
$0.5-1$ ha & 23 & 36.51 & 22 & 38.59 & 45 & 37.5 \\
1-3 ha & 8 & 12.69 & 13 & 22.81 & 21 & 17.5 \\
More than 3ha & 8 & 12.69 & 4 & 7.02 & 12 & 10 \\
Total & 63 & 100 & 57 & 100 & 120 & 100 \\
\hline
\end{tabular}

\section{Descriptive analysis}

To achieve the first objective i.e. to understand current situation of rice production in the Mekong Delta, the result from the survey were analyzed using descriptive statistics and gross margin analysis. Gross margin analysis include the budgeting analysis of cost and return from production and the calculation are as follows:

Yield per hectare: Total output/total area (ha)

Gross return (gross output value) $=$ Total output $\times$ Unit price

Variable cost: cost of used input such as cost of seed, fertilizers, pesticide, herbicide, fuel, irrigation charges, so on

Fixed capital services $=$ Owned machine depreciation + hired machine costs

Labor cost: Cost of hired labor +imputed family labor

Other cost: paying interest of borrowing, land use tax, paying land rent

Total cost $=$ Variable cost + fixed capital services + Labor cost + Other costs

Profit: Gross return -Total cost

Farm income $=$ Imputed family labor cost + profit

\section{Technical efficiency of rice farmers in different cropping seasons-the stochas-} tic frontier model

In order to identify the factors affecting rice yield and assess the technical efficiency of rice farmers in the Mekong Delta, the stochastic frontier production function approach is applied. A Cobb-Douglas stochastic frontier production function is assumed to be the appropriate model for analysis. The model specified for farmer in a given season is defined as:

$$
\operatorname{Ln} Y_{i}=\beta_{0}+\beta_{1} \ln X_{1 i}+\beta_{2} \ln X_{2 i}+\beta_{3} \ln X_{3 i}+\beta_{4} \operatorname{Ln} X_{4 i}+\beta_{5} \ln X_{5 i}+\beta_{6} \ln X_{6 i}
$$




$$
+\beta_{7} \ln X_{7 i}+\beta_{8} \ln X_{8 i}+V_{i}-U_{i}
$$

Where, the subscript $\mathrm{i}$ indicates the $\mathrm{i}$-th farmer in the sample.

$Y$ rice yield of farm (kg per hectare),

$X_{1}$ amount of seed sown (kg per hectare)

$X_{2}$ Nitrogen active amount $(\mathrm{kg} / \mathrm{ha})$

$X_{3}$ Phosphorus active amount ( $\left.\mathrm{kg} / \mathrm{ha}\right)$

$X_{4}$ Potassium active amount (kg/hectare)

$X_{5}$ Pesticide cost per hectare (1000 d/ha)

$X_{6}$ Labor used (man-day/ha)

$X_{7}$ Hired machine cost (1000 d/ha)

$X_{8}$ Farm size in cong $\left(1 \mathrm{cong}=1000 \mathrm{~m}^{2}\right)$

The $V_{i} s$ are random error that are assumed to be independently and identically distributed as $\mathrm{N}\left(0, \sigma_{\mathrm{v}}{ }^{2}\right)$.

The $U_{i} s$ are non-negative technical inefficiency effects that are assumed to be independently distributed among themselves and the $V_{i} s$, such as $U_{i}$ is obtained by the truncation (at zero) of the normal distribution with mean $\mu_{\mathrm{i}}$, and variance, $\sigma_{\mathrm{u}}{ }^{2}$, where $\mu_{\mathrm{i}}$ is defined by:

$$
\mu_{\mathrm{i}}=\delta_{0}+\delta_{1} Z_{1 i}+\delta_{2} Z_{2 i}+\delta_{3} Z_{3 i}+\delta_{4} Z_{4 i}+\delta_{5} Z_{5 i}+\delta_{6} Z_{6 i}+\delta_{7} Z_{7 i}+\delta_{8} Z_{8 i}
$$

Where:

$Z_{1}$ is the land dummy that equal to 1 if farmer has land holding more than 3 ha and 0 otherwise

$Z_{2}$ is the land dummy that equal to 1 if farmer has land holding from $1-3$ ha and 0 otherwise

$Z_{s}$ is variety dummy variable. $Z_{s}=1$ if farmer uses new variety and 0 otherwise

$Z_{4}$ is IPM participation dummy variable $Z_{4}=1$ if farmer participates in IPM program and 0 otherwise

$Z_{5}$ is sowing technique dummy variable. $Z_{5}=1$ if row seeding techniques is used and 0 otherwise.

$Z_{6}$ is education attainment of household head (year of schooling)

$Z_{7}$ is market access ability variable, dummy variable having a value of 1 if the farm has easy access to market and zero otherwise.

$Z_{8}$ is availability of production credit-this refers to total amount of production loan of the farmers, in million VND.

The $\delta_{\mathrm{i}} \mathrm{s}$ are unknown parameters to be estimated.

Stochastic frontier model is estimated separately for each rice season. This approach permits the frontier models to be different for the different growing season. Several statistical test of null hypotheses of interest for the stochastic frontier model were conducted using likelihood ratio test. These test were used to select the preferred frontier models for the presentation of empirical results.

\section{Allocative efficiency and examination of allocative efficiency}

As mentioned above, economic efficiency refers to two components: technical efficiency and allocative efficiency. Technical efficiency can be defined as the ability to achieve a higher level of output, given a same level of production inputs. Both technical and allocative efficiency are necessary and sufficient conditions for achieving economic 
efficiency. It could be said that the estimated technical efficiency of farm production is just able to find out the gap between the actual output level and potential output level. The actual output level is the result of physical input combination, which do not concerns on the two important indicators leading the production profit, namely: the input price and output price. An question was that whether the sample households with their estimated level of technical efficiencies were able to obtain the optimum input used to achieve its economic efficiency. Therefore, the investigation of allocative efficiency should be done to answer this question. But it should be noted here that no risk is considered in the model of this paper.

\section{Examination of allocative efficiency}

Allocative efficiency was interpreted as the extent to which farmers make efficient decisions by using inputs up to the level at which their marginal contribution to output value is equal to the factor cost. The method of examination is presented as follows:

The output elasticity of an input, $X_{i}$, denoted by $\omega_{i}$, is defined as the proportionate rate of change of output, $Q$, with respect to $X_{i}$ :

$$
\begin{aligned}
& \omega_{i}=\frac{\partial\left(\ln q_{i}\right)}{\partial\left(\ln x_{i}\right)}=\frac{x_{i}}{q_{i}} \frac{\partial q_{i}}{\partial x_{i}}=M P_{X i} \frac{x_{i}}{q_{i}} \quad(i=1,2, \ldots, n) \text { (Henderson and Quandt, 1980) } \\
& \text { or } \quad M P_{X i}=\omega_{i} \frac{q_{i}}{x_{i}} \\
& \quad \text { and } \quad M V P_{X i}=M P_{X i} P
\end{aligned}
$$

$M P_{X i}$ is Marginal Product of input $X_{i}$, which is the rate of change of its total production with respect to variation of $X_{i}$ quantity.

$M V P_{X i}$ is the marginal value product of input $X_{i}$, and it is the product of marginal product of input $X_{i}, M P_{X i}$, and output price, $\mathrm{P}$ ( rice price).

Since $M V P_{X i}$ represents the return generated by the additional unit increment of an input $X_{i}$, this should just cover the unit price of that input. Thus, the $M V P_{X i}$ value is referred for determining the profitability of the last additional unit of any input by farm managers. Farmer would attain the allocative efficiency if

$M V P_{X i}=P_{X i} \quad$ or $\quad \frac{M V P_{X i}}{P_{X i}}=1$

where $P_{X i}$ is the price of input $X_{i}$

Let introduce the notation $r_{X i}=\frac{M V P_{X i}}{P_{X i}} \quad$ (7) which is the ratio between marginal value product of input $X_{i}$ and the price of that input. We carried out the hypothesis test:

$H_{0}: r_{X i}=1 \quad$ (Farmer achieved the allocative efficiency)

$H_{1}: r_{x i} \neq 1 \quad$ (Farmer did not achieved the allocative efficiency)

the following formula is used to test the above hypothesis

$t=\frac{\bar{r}-r_{0}}{s} \sqrt{\mathrm{n}-1}$

where $\bar{r}$ is the mean of $\mathrm{n}$ value of $r_{X i}$

$r_{0}$ is equal to 1 
$\mathrm{s}$ is the standard deviation of $\mathrm{n}$ value of $r_{x i}$

$\mathrm{n}$ is the number of observation of the sample

Given significant level $\alpha$, we look up the Student distribution table with (n-1) degree of freedom and we have the critical value $t_{n-1(\alpha / 2)}$. Comparing calculated $\mathrm{t}$ and $t_{n-1(\alpha / 2)}$, if

$$
|t| \geq t_{n-1(\alpha / 2)} \quad \text { Reject } \mathrm{H}_{0} \quad|t|<t_{n-1(\alpha / 2)} \quad \text { Accept } \mathrm{H}_{0}
$$

Moreover if $r_{x i}>1$ mean that Xi should be increased to achieve allocative efficiency. if $r_{x i}<1$ mean that Xi should be decreased to achieve allocative efficiency.

\section{ECONOMICS OF RICE PRODUCTION IN THE MEKONG DELTA}

\section{Rice farming practices \\ Land preparation and rice sowing}

For the first crop (winter-spring crop), starting at the end of August most farmers (90\%) plowed their field and then let their field under water during the flooding period from September to October. During the flood season, water depth in the field rises to about 0.5 to $0.6 \mathrm{~m}$. After the flood, that is by beginning of November, farmers start to repair dikes and canals and level field before sowing. At that time, winter-spring rice (dong-xuan) is cultivated and the tractors are used to puddle the field when the water level is about $5 \mathrm{~cm}$ and farmers broadcast the germinated seeds. The field has to be kept moist until the seedlings grow to $3-4 \mathrm{~cm}$, for which water is kept in the field permanently. Harvesting of winter-spring rice takes place when the field is totally dry.

The cultivation of the second crop spring-summer (xuan-he) is completely different from those of winter-spring rice and summer-autumn rice. This is called "Sa chai" in the Mekong Delta. The field is kept dry and it neither ploughed nor puddle, but before broadcasting the seed, the straw of the previous crop is spread over the rice stubble and burnt. After burning, germinated rice seeds are broadcasted on the field followed by a quick surface irrigation. Some farmers also broadcast dry rice seeds directly in the field, and then water is kept for one night to promote germination. The reason for choosing this method is mainly due to limited time to plough the field to cultivate the spring-summer rice. Moreover, if spring-summer rice planted by wet broadcasting, the soil would have to be puddled and this would not be practicable in the dry season because of the lack of rain.

After harvesting spring-summer rice, the soil is ploughed and dried for summer-autumn crop (he-thu). About $23.18 \%$ of farmers plowed their field and about $10.45 \%$ burned straw, plowed and harrowed their fields. Others merely spread the rice straw on the filed to burn and ashes were left on the field as fertilizer and irrigated their field in order to loosen the soil before sowing. When the first rains come, the farmers puddle the field with tractor and broadcast germinated seed. Irrigation is sometimes required at the start of rainy season. This summer-autumn rice has a very short growing period. In general there are several methods of land preparation applied or practiced by the farmers in the study area. The ratio of farmers using such method is illustrated in the Table 2.

Farmers no longer use buffaloes or cattle for plowing or harrowing their fields. From the survey, it is found that $100 \%$ of the sampled households hired tractor or use their own machine for land preparation. In each village or commune, there are some households 
Table 2. Land preparation methods

\begin{tabular}{lcc}
\hline \multirow{2}{*}{ Method } & \multicolumn{2}{c}{ Ratio (\%) } \\
\cline { 2 - 3 } & Winter-spring & Summer-autumn \\
\hline Plowing & 75.5 & 23.18 \\
Straw burning and plowing & 15.5 & 10.45 \\
Sowing directly & 10.0 & 16.36 \\
Straw burning and dry harrowing & - & 12.72 \\
Dry harrowing & - & 13.63 \\
Straw burning and wet harrowing & - & 20.90 \\
Others & - & 3.06 \\
\hline
\end{tabular}

Source: Survey 2002

providing such services. The small tractors manufactured in China are very popular and suitable for the fields in the Mekong Delta. Although varying from group to group, on an average about 300 thousand VND is charged for hiring the tractor to plough a hectare of land. On the other hand the households in groups 4 and 5 spent about 50-100 thousand VND less than other groups in land preparation enjoying the benefits of economy of scale by the large landholding.

Based on the observation and survey findings it is found that almost all the farmers applied direct sowing method, an old practice of planting rice in the Mekong Delta which is different from the popular transplanting method practiced in the Red River Delta in the north. About $8.33 \%$ of farmers use the method so called "sowing by row" (Table 3). By using such advanced appliance, seed wastage is saved and it is convenient for weeding.

Table 3. Sowing method applied by group (Unit: \%)

\begin{tabular}{lrrrrrc}
\hline \multicolumn{1}{c}{ Method } & Average & Group1 & Group2 & Group3 & Group4 & Group5 \\
\hline Seed broadcasting & 91.67 & 100 & 100 & 91.11 & 85.71 & 75 \\
Seeding by row & 8.33 & 0 & 0 & 8.89 & 14.29 & 25 \\
\hline
\end{tabular}

Source: survey 2002

The seeding rate used varies across crop season, methods used for sowing /seeding, and household groups. Overall, the farmers used more seed in winter-spring than in summer-autumn crop. Most of the farmers in groups 4 and 5 have adopted new variety and as such use less quantity of seeds compared to other groups. However, in terms of money, they may spend more for seed, because the price of modern improved variety seed is usually more costly than traditional and old ones (Table 4).

Table 4. Quantity of seed used by group of farmer (Unit: kg/ha)

\begin{tabular}{lcrrrrr}
\hline \multicolumn{1}{c}{ Indicator } & Average & Group 1 & Group 2 & Group 3 & Group 4 & Group 5 \\
\hline Seeding rate & 219.42 & 242.08 & 235.99 & 218.45 & 198.97 & 201.69 \\
Seed price (1000 VND/kg) & 1.78 & 1.57 & 1.81 & 1.73 & 1.90 & 2.15 \\
\hline
\end{tabular}

Source: survey 2002 


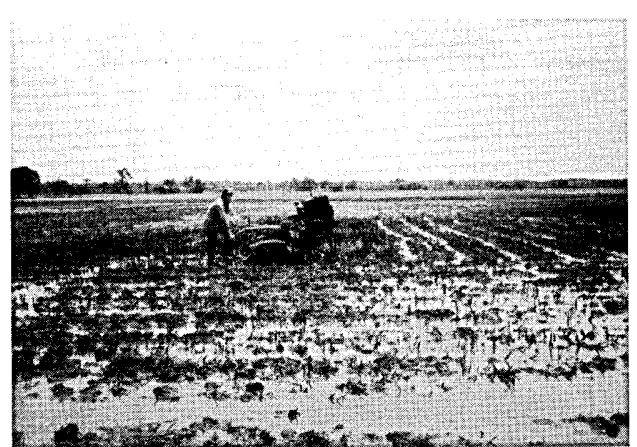

Picture 1. Land harrowing

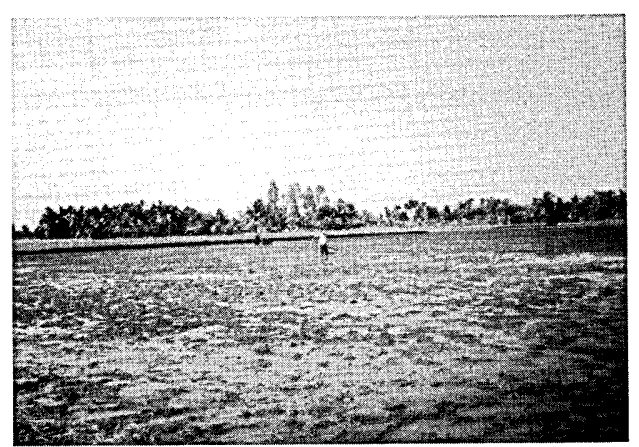

Picture 2. Land preparation

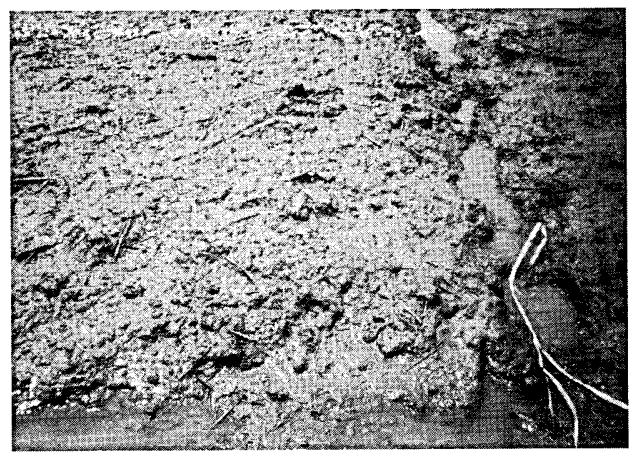

Picture 3. Rice sowing

\section{Weed control}

Using herbicide combined with hand weeding is more popular in the Mekong Delta. The frequency of hand weeding varied from 0 to 5 times with an average of twice per season. About $90 \%$ of the farmers in the study area used herbicide for weed control. Only $5.83 \%$ reported of not using herbicide mainly due to proper clearance during the land preparation and also used water to exterminate weed. About $4.17 \%$ of farmers,

Table 5. Methods used in and expense for weed control (Unit: \%)

\begin{tabular}{lcccccc}
\hline \multicolumn{1}{c}{ Indicator } & Average & Group 1 & Group 2 & Group 3 & Group 4 & Group 5 \\
\hline Use herbicide & 90.0 & 83.33 & 86.67 & 93.33 & 85.71 & 100 \\
Not use herbicide & 5.83 & 0 & 3.33 & 6.67 & 14.29 & 0 \\
Only hand weeding & 4.17 & 16.67 & 10.0 & 0 & 0 & 0 \\
Expense for herbicide & 145.12 & 94.33 & 119.80 & 132.83 & 186.75 & 284.85 \\
(1000 VND/ha/crop & & & & & & \\
\hline
\end{tabular}

Source: survey 2002 
mostly form group 1 and 2 have reported doing hand weeding mainly due to lack or money to buy herbicide (Table 5).

\section{Fertilizer application}

No farmers have reported applying manure on their rice field. The interview revealed the reasons for this phenomenon, those are: (1) Because the livestock production in the Mekong Delta at the farm level has not developed, therefore the small amount of manure from livestock rearing are mainly used in the home garden; (2) Farmers in the Mekong Delta still do not have practice/habit to use manure for the rice; (3) The knowledge of farmers about the effect, advantage and benefit of manure use to land fertility still is limited.

All the farmers in the study area used chemical fertilizers for rice in all seasons. The number of fertilizer application ranged from twice to 5 times with an average of 3.2 times. In general farmers applied fertilizer 3 times, the first one after sowing 7-10 days, the second one after 20 days and the third application done after 35 days from the second application. Then after that farmers used pesticide, and other fertilizers applying on the rice leaves.

The common types of fertilizer used on the rice field are Urea, DAP, NPK, KCl. SP, $\mathrm{SA}$, and so on. The dosage varied by season and groups of farmers. Farmers tend to use more chemical fertilizer in the winter-spring than other crops, but the difference is not significant. However, the dosage or rate of fertilizer use by the farmers changed with the change in fertilizer price. For instance, farmers substituted DAP by NPK when there is relative increase in the price of DAP or farmers tend to use less fertilizer when the price of fertilizer increases. Since farmers of group 1 or/and 2 are mostly poor households, often they do not have enough money to buy fertilizer, therefore, the dosage of fertilizer application is less compared to groups 4 or 5 (Table 6).

Table 6. Average quantity of main fertilizers applied by group (Unit: $\mathrm{kg} / \mathrm{ha} / \mathrm{crop}$ )

\begin{tabular}{ccccrcc}
\hline Indicator & Average & Group 1 & Group2 & Group 3 & Group 4 & Group 5 \\
\hline Urea & 133.51 & 123.33 & 134.50 & 132.89 & 120.26 & 166.67 \\
DAP & 138.33 & 156.67 & 130.32 & 120.86 & 112.35 & 150.00 \\
NPK & 111.49 & 12.5 & 113.07 & 123.17 & 130.88 & 128.79 \\
KCl & 7.77 & 0.00 & 6.94 & 8.56 & 14.46 & 2.4 \\
\hline
\end{tabular}

Source: survey 2002

If compared to other Asian countries, the use of inorganic-fertilizer by the farmers in the Mekong Delta is relatively high. Due to the prevalence of unbalanced use of nitrogen, phosphorus and potash, the soil nutrient mining is continuing, particularly with respect to potash.

\section{Pest and disease control}

The survey shows that farmers themselves make decisions on pest and disease management activities. The farmers visited their field once a day or at least once every two days. By the observation in the field visit, the farmers are able to recognize the appearance of pest or diseases in the field.

All the farmers in the study area were aware of the importance of chemical methods 
in controlling insects and diseases. Most of the farmers in the study area used pesticides for pest control. About $93.33 \%$ of the total sampled farmers have reported of using insecticides and fungicides, whereas $16.67 \%$ of the total farmers in group one and $6.67 \%$ from group 2 have reported not using pesticide in their field mainly due to the lack of capital and money to buy chemical pesticide. Some farmers from group 3 about $8.89 \%$ used other methods such as duck and water management or IPM method to control pests (Table 7).

Table 7. Ratio of household using pesticide and expense in pest and disease management

\begin{tabular}{lrrrrrc}
\hline \multicolumn{1}{c}{ Indicator } & Average & Group 1 & Group 2 & Group 3 & Group 4 & Group 5 \\
\hline Use pesticide (\%) & 93.33 & 83.33 & 93.33 & 91.11 & 100 & 100 \\
Not use pesticide (\%) & 6.67 & 16.67 & 6.67 & 8.89 & 0 & 0 \\
Pesticide expense & 247.21 & 112.35 & 325.22 & 200.3 & 238.09 & 378.87 \\
(1000 VND/ha/crop) & & & & & & \\
\hline
\end{tabular}

Source: survey 2002

IPM (Integrated Pest Management) program has been promoted since 1992. The program aimed to increase the knowledge of farmers for better decision making in rice production leading to more sustainable production and greater farm level benefit. Every year, agricultural extension centers of provinces in coordination with the agricultural extension office of commune organize many training courses on IPM for farmers. Those courses have brought many benefits for farmers.

As seen in the table 8 about $15.5 \%$ of farmers followed the IPM method in pest management. However, the common way to treat pest and disease was that farmers applied pesticide to control pest when there was pest infestation in their rice field (45.9\%). About $14.5 \%$ of farmers answered that they applied pesticides to prevent pest in their rice field even when there was no sign of pest attack. About $18.2 \%$ of farmers applied preventive spray during critical period when they thought that pest infestation was most likely to occur and curative spraying during other period.

The expense for pesticide per hectare in each crop ranged from 112.35 thousand VND to 378.87 thousand VND with average of 247.21 thousand VND (Table 7). Expenditure for herbicide and pesticide were much higher in the Mekong Delta (roughly about 3 times higher) compared to those in Red River Delta. Therefore, the relevant attention should

Table 8. Methods of pest and disease management applied by farmers

\begin{tabular}{lc}
\hline Method & Rate (\%) \\
\hline 1 IPM method & 15.5 \\
2 Curative spray & 45.9 \\
3 Preventive spray & 14.5 \\
4 Combination of preventive and curative spray & 18.2 \\
6 Other methods & 5.9 \\
\hline
\end{tabular}

Source: Survey 2002 


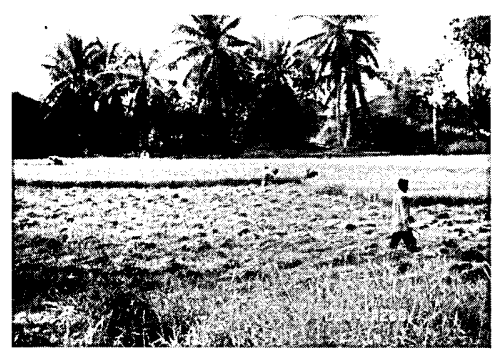

Picture 4. Rice harvesting

be given to make agriculture more environmentally friendly and to make product safer.

\section{Harvesting}

The machine is used by all the households (100\%) for land preparation, but simple tools like sickle is used for harvesting by almost all of them resulting into low labor productivity. On an average they spend more than 20 man-days per hectare per crop for cutting and the difference between groups is not significant. However, there was a

Table 9. Labor used for harvest activity, wage of hired labor and cost of rent threshing machine per hectare by rice crop

\begin{tabular}{lcc}
\hline \multicolumn{1}{c}{ Crop } & Winter-spring & Summer-autumn \\
\hline Labor (man-day) & 16 & $22-30$ \\
Wage of hired labor (1000 VND/man-day) & 25 & $28-40$ \\
Threshing charge (1000 VND) & 300 & 320 \\
\hline
\end{tabular}

Source: Survey 2002

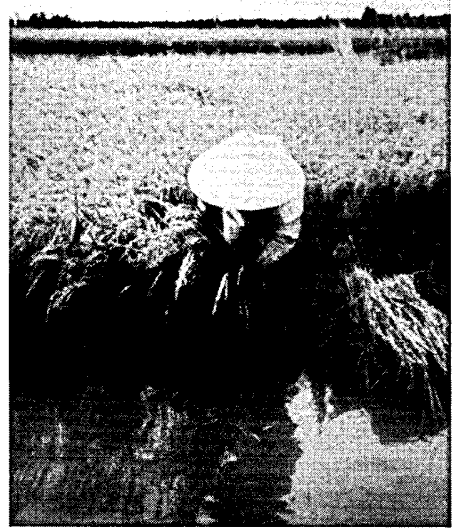

Picture 5. Rice cutting 
difference between the seasons, the summer-autumn crop required more labor for harvesting than other crops due to the harvesting being required to finish within very short time in order to avoid the flood, and sometimes logged rice makes it difficult for harvesting. This has therefore increased the wage rate of hired labor by 1.1-1.6 times compared to winter-spring season.

The shortage of hired labor is a common problem during this season mainly due to various reasons such as: in recent years, almost all the farmers broadcast their seed more or less on the same time in all the fields, as a result rice matures almost at the same time, leading to increased demand for harvesting labor. Moreover, many young labors in rural now migrate to cities and towns or industrial areas in search of off time job further hampering the farm labor situation in the rural areas. The households with large rice fields are not able to get adequate hired labor despite their willingness to pay 600 thousand to 800 thousand VND per hectare for rice cutting. Although many types of harvesting machines have been introduced in to the Mekong Delta, most has been found to unsuitable for the Mekong Delta. The main reason was that to use the cutting machine, rice should be straight, but usually at the time of harvest, due to wind and rain; often the rice is logged and as a result the use of machine becomes difficult. Moreover, after cutting, rice is laid down on the field, and again farmers should use labor for collecting and carrying to threshing machine. Therefore, even though with the help of rice cutting machine the problem of shortage of labor during the harvesting is still not yet solved.

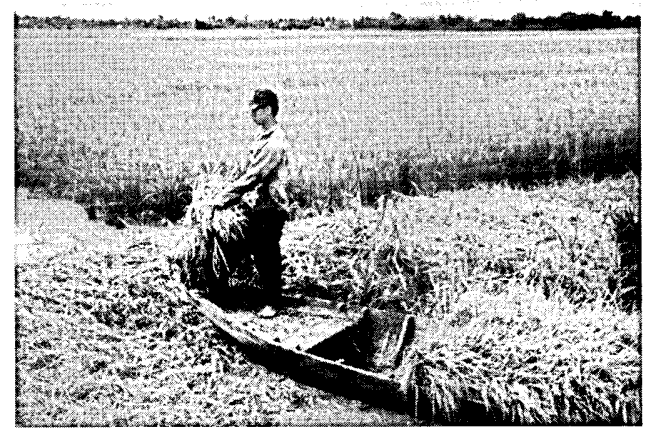

Picture 6. Rice carrying

Right after harvesting, rice is threshed in the fields by rented thresher machine and almost all the farmers used machine for threshing. At present, in the Mekong Delta ambulatory service for rice threshing with capacity from 1-3ton per hour is found to be very popular. The service charge ranged from 300-350 thousand VND per hectare per crop. Due to use of machine for threshing the productivity has increased by 6 times higher than before and the rate of rice loss was considerably reduced. However, the loss during this period was still high with $1.4-1.8 \%$ of total output on an average and sometimes $3-5 \%$ in summer-autumn crop.

Significant losses in quality and quantity occurred during the post harvest including pre storage activities such as threshing, drying, cleaning and transporting; storage and milling activities such as hulling, grading, whitening and polishing. The losses varied 


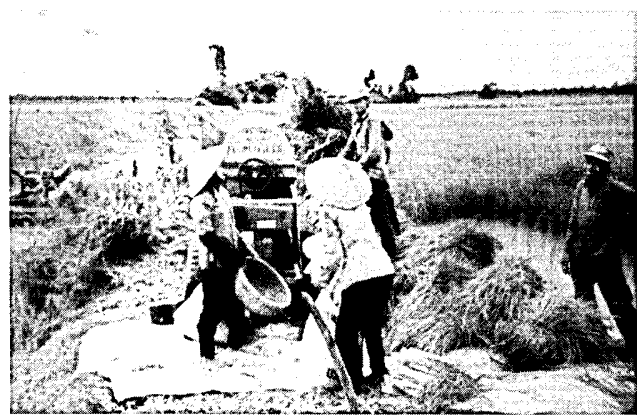

Picture 7. Rice threshing

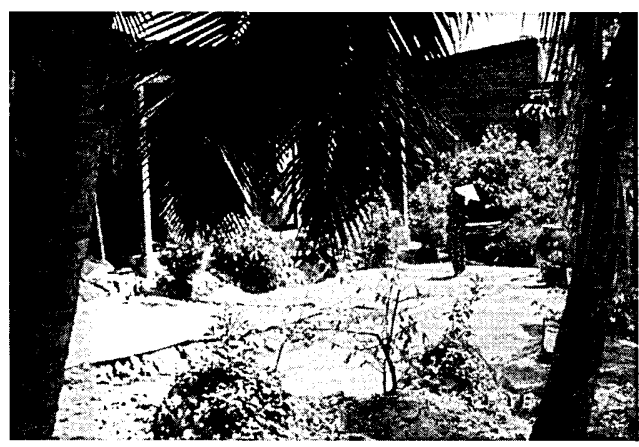

Picture 9. Rice drying

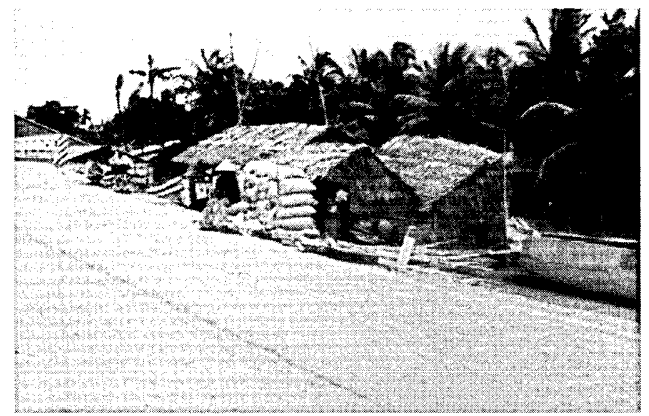

Picture 8. Drying rice on the road

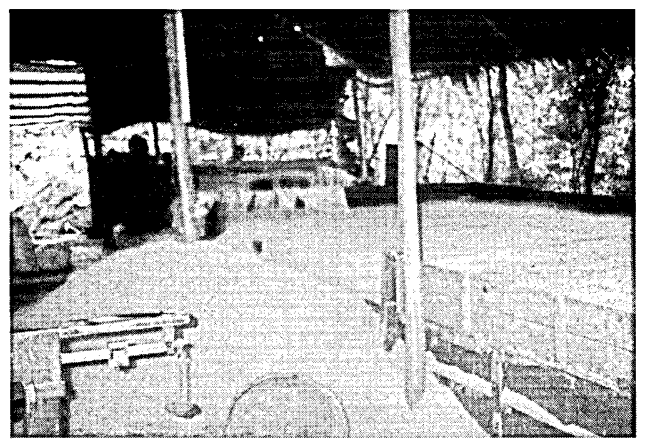

Picture 10. Drying by dryer

between $13-16 \%$ of output in whole country, and the figure is higher in the Mekong Delta since the infrastructure was very poor (IFPRI-MARD).

Drying was still rudimentary and subject to heavy losses. Farmers dried paddy under the natural sun heat ray ( $75 \%$ of production). The groups of farmers with large-scale have brick-yard to dry paddy or hire the drying machine whilst the groups of farmers with small scale usually dried paddy on the road. They were not able to use the machine service for drying paddy mainly due to the high service charges. Moreover, due to small rice output they were also not able to fully utilize the total machine capacity, and consequently the cost of drying per kilogram is increased. The hiring charge for the drying machine ranged from 80 thousand to 150 thousand VND per hectare per season depending on the quality of paddy and season. The expense for the drying machine is increased during the summer-autumn mainly due to the rain and flood at the time of the harvest.

\section{Rice variety}

Majority of farmers in the Mekong Delta use high yielding varieties, and the traditional varieties are found only in the region where floating rice is cultivated. However, rice varieties here are classified into 2 groups of old and traditional versus new, modern ones. 
The rice varieties considered as old ones are those varieties released several years ago, infected easily with disease and low quality such as IR50404, IR50401, F18, F84, 96-6, 979-6, and so on. The modern varieties are those released in the recent years, which are of high quality and yielding, and disease resistant varieties. Varieties in this group included IR1907, IR1960, CS98, CS97, Jasmine, VND5-20, Khaodawkmali, and so on. The ratio of households using different types of varieties is illustrated in the table 10. The number of household using old varieties ranged from 16.67 to $91.67 \%$ with an average of $67.50 \%$. Most of the households of group 1 used old varieties in their field, and this varied from group to group with $86.67 \%, 44.44 \%, 42.86 \%$ and $16.67 \%$ for groups $2,3,4$, and 5 , respectively.

Table 10. Type of varieties used by group

\begin{tabular}{ccccccc}
\hline Indicator & Average & Group 1 & Group 2 & Group 3 & Group 4 & Group 5 \\
\hline Old variety & 56.67 & 91.67 & 86.67 & 44.44 & 42.86 & 16.67 \\
New variety & 43.33 & 8.33 & 13.33 & 55.56 & 57.14 & 83.33 \\
\hline
\end{tabular}

Source: survey 2002

Regarding the new variety, only $8.33 \%$ farmers of group 1 cultivated new variety while about $83.33 \%$ of farmers in the group 5 cultivated the new variety. On an average about $43.33 \%$ of the households used new varieties with higher yield, small seed rate, and good quality, but the seed cost is higher compared to the old variety, and as such the poor farmers are unable to afford to use improved varieties. However, sometimes due to the indifference between the selling paddy prices old and new varieties, farmers are not encouraged to cultivate new varieties. It is fearful that many farmers will go back to use old varieties, many of which are already in serious degeneracy like IR 50404, Ham Trau.

The households in the study area get their paddy seeds from five different sources such as; (1) From the sale agents, (2) Seed recommended by local extension agents (3) From friends, neighbors or local market, (4) Own farm from previous season and (5) From universities or research institutes such as Can Tho University, Omon Rice Research Institute, Cuu Long Rice Research Institute or Song Hau State Farm. As shown in the table 11, friends, neighbors or local markets and their own farm remain the main source of seed, approximately accounting $25.83 \%$ and $20.83 \%$ respectively. The seed bought from University or Research Institutes and Extension Agents accounted small number of $9.17 \%$ and $15.83 \%$ respectively. This indicates the inefficient performance of the

Table 11. Sources of seed (Unit:\%)

\begin{tabular}{lcccccc}
\hline \multicolumn{1}{c}{ Source } & Average & Group 1 & Group 2 & Group 3 & Group 4 & Group 5 \\
\hline 1 Sale agents & 28.33 & 41.67 & 23.33 & 26.67 & 28.57 & 33.33 \\
2 Extension agents & 15.83 & 0 & 20.0 & 13.33 & 14.29 & 33.33 \\
3 Friend, neighbor, local market & 25.83 & 33.33 & 23.23 & 26.67 & 33.33 & 8.33 \\
4 Own farm & 20.83 & 25.0 & 23.23 & 24.44 & 14.28 & 8.33 \\
5 University, Research Institute & 9.17 & 0.0 & 10.0 & 8.89 & 9.52 & 16.67 \\
\hline
\end{tabular}

Source: survey 2002 
concerned agents involved in introduction and recommendation of new varieties for an area to be considered for the future improvement. The convenience and reasonable prices are the two main reasons for the farmers to choose the source from where to buy their seed.

\section{Labor use}

Calculating labor use for rice production in the Mekong Delta was complicated due to the large variation between households and seasons. Households with the small land scale usually used family labor for almost all rice production activities except machine being hired for land preparation and threshing. While most of the households with large land scale hired labor for all the rice production activities. The total labor used for one hectare of rice per season ranged from 51-62 man-days with an average of 58.95 man-day of which the family labor spent for one hectare in one season ranged from 25 to 62 man-days with an average of 44.48 man-days accounting for $75.45 \%$ of the total labor in rice production. Households of groups 4 and 5 hired labor more than the other groups. They usually use hired labor in land preparation such as cleaning the filed, fertilizing, pesticide spraying, harvesting and transporting. For households of groups 1 and 2 due to small landholdings and surplus labor they have, they did almost all the activities of rice production by themselves and even hired out their labor during the peak season. (Table 12)

Table 12. Allocation of family labor and hired labor in rice production by group

\begin{tabular}{ccrcccl}
\hline Activity & Average & Group 1 & Group 2 & Group 3 & Group 4 & Group 5 \\
\hline Family labor (man-day) & 44.48 & 62 & 58 & 45 & 27 & 25 \\
Ratio in total labor (\%) & 75.45 & 100 & 95.08 & 74.38 & 50.0 & 49.02 \\
Hired labor (man-day) & 14.48 & 0 & 3 & 15.5 & 27 & 26 \\
Ratio in total labor (\%) & 24.55 & 100 & 4.92 & 25.62 & 50 & 50.98 \\
Total labor (man-day) & 58.95 & 62 & 61 & 60.5 & 54 & 51 \\
\hline
\end{tabular}

Source: Survey 2002

Table 13. Use of labor in rice production (Unit: man-day)

\begin{tabular}{|c|c|c|c|c|c|c|}
\hline Activity & Average & Group 1 & Group 2 & Group 3 & Group 4 & Group 5 \\
\hline Land preparation & 16.68 & 18 & 18 & 18 & 13 & 11 \\
\hline Sowing & 3 & 3 & 3 & 3 & 3 & 3 \\
\hline Replanting & 4.75 & 5 & 5 & 5 & 4 & 4 \\
\hline Weeding & 2.53 & 3 & 3 & 2.5 & 2 & 2 \\
\hline Irrigation & 1.75 & 2 & 2 & 2 & 1 & 1 \\
\hline Fertilize application & 5 & 5 & 5 & 5 & 5 & 5 \\
\hline Pesticide spray & 2.03 & 3 & 2 & 2 & 2 & 2 \\
\hline Harvest & 13.21 & 13 & 13 & 13 & 14 & 13 \\
\hline Threshing & 1 & 1 & 1 & 1 & 1 & 1 \\
\hline Drying & 7 & 7 & 7 & 7 & 7 & 7 \\
\hline Transport & 2 & 2 & 2 & 2 & 2 & 2 \\
\hline Total & 58.95 & 62 & 61 & 60.5 & 54 & 51 \\
\hline
\end{tabular}

Source: survey 2002 


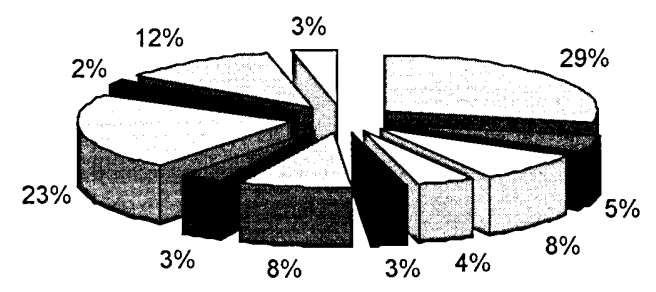

\begin{tabular}{|lll|}
\hline$\square$ Land preparation & $\square$ Sowing & $\square$ Replanting \\
$\square$ Weeding & $\mathbf{E}$ Irrigation & $\square$ Fertilize application \\
$\mathbf{m}$ Pesticide spray & $\square$ Harvest & $\square$ Threshing \\
$\square$ Drying & $\square$ Transport & \\
\hline
\end{tabular}

Figure 3. Structure of labor in rice production

The details of labor allocation for each activity of rice production are presented in the table 13 and figure 3 . As seen in the table and the figure, the activities like land preparation, replanting, fertilizer application, harvesting and drying occupied a big proportion accounting for $29 \%, 8 \%, 8 \%, 23 \%$ and $12 \%$ in total labor respectively. Therefore, households often face labor shortage problem during the peak season especially during harvesting period.

\section{Hired equipment}

For some activities such as land plowing and harrowing, threshing, water pumping, or paddy drying, almost all the farmers used or shared services provided by the state farm and some households or group of households. The charges for such kind of services are based on the cultivated area of the household or on total output. Therefore, there are no significant differences on the rates between groups and seasons, except that large landholding households owning some equipment have the privilege to use their equipment based on their priority and thereby to reduce loses. The expenses for hired equipment is quite high in the total cost per hectare accounting for $20-30 \%$.

\section{Technology information, training, and credit}

Concerning the sources of information on technique and technology, about $33.33 \%$ of farmers considered the information they get from friends and other farmers as the most important source, while for $26.67 \%$ extension appeared as an important source and for $26.67 \%$ the television or other mass media are important. The information from local leaders and books, newspapers played very minor role. However, the ratio is found slightly different between the groups of farmers. Farmers of groups 4 and 5 considered television, radio the most important sources, while the farmers in groups 1,2 considered friends as the most important source of information.

\section{Training course}

Extension activities have been operated regularly in the area. On an average about $39.17 \%$ of the respondent farmers has participated in the training course organized by 
local agricultural extension office. However, the ratio of participation varied by groups of farmers. It was found that farmers in groups 4 and 5 have higher ratio of participation in training course than those in other groups (Table 14), and even reported of having benefited from the course in terms of knowledge. On the contrary, farmers participation from the group one is found to be very low, mainly due to limited landholding, they need to work outside to earn more income, as such it is difficult for them to find the time to take part in the training courses and also have less interest for participation.

Table 14. Participation of farmers on farming training course

\begin{tabular}{ccccccc}
\hline $\begin{array}{c}\text { Participation on training } \\
\text { course }\end{array}$ & Average & Group 1 & Group 2 & Group 3 & Group 4 & Group 5 \\
\hline Yes & 39.17 & 25.0 & 40.0 & 35.56 & 42.86 & 58.33 \\
No & 60.83 & 75.0 & 60.0 & 64.44 & 57.14 & 41.67 \\
\hline
\end{tabular}

Source: survey 2002

The training courses are usually provided on agricultural production techniques like using new varieties, fruit tree growing, fertilizer application, pest and disease prevention, and on integrated pest management (IPM) program. On average about $37.5 \%$ of the total respondents have participated in IPM course, with higher participation from farmers in groups 4 (66.67\%) and $5(41.17 \%)$ while only $33.33 \%, 42.86 \%$ and $30.56 \%$ in groups 1,2 and 3 respectively participated in IPM course. According to farmers' assessment, they are able to reduce expenses on pesticides with the adoption of the IPM measures and methods.

\section{Credit}

As seen in the table 15 , about $47.5 \%$ of farmers have reported borrowing money from both formal and informal sources, and it also varied by group of farmers, ranging from $33.3 \%$ in group 1 to $66.67 \%$ in group 5 . The main sources of credit for farmers came from government banks and other informal institutions. Agricultural and Rural Development Banks and Bank for the Poor are the main sources of borrowing with more than $75 \%$ of the farmers having taken loan from them, indicating the importance of their role in rural credit activity nowadays and the rest $25 \%$ came from different sources like agricultural cooperative, women union, friends, neighbors and relatives.

The People's Committees at the village levels are involved in selecting the borrowers. The Vietnam Bank for the Poor (VBP) provides loans according to list of poor households submitted to it by the People's committees, which gives the committees a large amount of sway in lending decisions. Also involved in VBP lending are the farmer association and women's unions. In addition to candidate's selection, these organizations also play major

Table 15. PRatio of household having loan

\begin{tabular}{ccccccc}
\hline Did HH borrow money & Average & Group 1 & Group 2 & Group 3 & Group 4 & Group 5 \\
\hline Yes & 47.5 & 33.333 & 38.095 & 44.444 & 64.706 & 66.667 \\
No & 52.5 & 66.667 & 61.905 & 55.556 & 35.294 & 33.333 \\
\hline
\end{tabular}

Source: survey 2002 
Table 16. The sources of loan

\begin{tabular}{lrccccc}
\hline \multicolumn{1}{c}{ Source } & Average & Group 1 & Group 2 & Group 3 & Group 4 & Group 5 \\
\hline Agricultural and RD bank & 71.05 & 100 & 62.5 & 56.25 & 90.91 & 100 \\
Commercial bank & 2.63 & 0 & 0 & 6.25 & 0 & 0 \\
Bank for the poor & 5.26 & 0 & 12.5 & 6.25 & 0 & 0 \\
Farmers' association & 0 & 0 & 0 & 0 & 0 & 0 \\
Women' onion & 2.63 & 0 & 0 & 6.25 & 0 & 0 \\
Informal source & 21.05 & 0 & 25 & 31.25 & 9.09 & 0 \\
\hline
\end{tabular}

Source: survey 2002

roles in monitoring borrowers and recovering funds.

The amount of loan ranges from 1785.7 thousand VND to 12500 thousand VND with an average of 4880.63 thousand VND in the year 2000, and 5440.64 thousand VND in the year 2001. Farmers of group 5 could loan five times larger borrowing amount than that of group 1. Farmers usually use the credit for agricultural activities like purchasing inputs for rice production, buying new machinery and tools, investing in livestock production, and garden (Table 17).

About $48.52 \%$ of the farmer respondents have reported of not borrowing mainly because they did not require. This can be interpreted that either they have enough capital (usually found in high-income farmers of group 5) or they don't have any special plan in investment. About $17.64 \%$ of farmers, especially those of groups 1 and 2 claimed that they hesitate in borrowing money because they are afraid of risk. They do not know what to do and how to use the loan. Those farmers usually have very little land and low-education qualification. About $26.47 \%$ of farmers states that they need credit for agricultural activities, however, it has been reported that the access to credit being very difficult for them (Table 18).

Table 17. Average volume of loan (Unit: $1000 \mathrm{VND})$

\begin{tabular}{ccccccc}
\hline Year & Average & Group 1 & Group 2 & Group 3 & Group 4 & Group 5 \\
\hline 2000 & 4880.63 & 1785.7 & 3483.3 & 5041.7 & 7800 & 10000 \\
2001 & 5440.64 & 2000 & 2565.2 & 6041.7 & 7000 & 12500 \\
\hline
\end{tabular}

Source: survey 2002

Table 18. Reasons for not borrowing (Unit: \%)

\begin{tabular}{lcrrrrc}
\hline \multicolumn{1}{c}{ Reason } & Average & Group 1 & Group 2 & Group 3 & Group 4 & Group 5 \\
\hline No need & 48.52 & 0.0 & 31.58 & 72.0 & 54.55 & 60.0 \\
Very in need but cannot access & 26.47 & 62.5 & 36.84 & 16.0 & 18.18 & 0 \\
Being afraid of risk & 17.64 & 37.5 & 32.58 & 8.0 & 9.09 & 0.0 \\
Small amount & 7.35 & 0.0 & 0.0 & 4.0 & 18.18 & 40.0 \\
\hline
\end{tabular}

Source: survey 2002 


\section{Rice yield}

In general winter-spring paddy crop is the main crop grown with the largest sowing area. Highest rice yields are obtained for winter-spring crop due to favorable temperature and weather, taking full advantage of previous flood tide such as cleansed alum and accumulated alluvial soil. Yield of rice in winter-spring crop ranged from 5.86 to 6.33 ton with an average of 6.11 ton per hectare. The average yields of rice in summer-autumn crop and spring-summer are 4.31 and 3.96 ton/ha, respectively as shown in the table 19 and figure 4.

However, the yields are still low compared to Red River Delta and other countries. In future if the irrigation is improved, the potential of obtaining increased of yield can be exploited.

According to $75 \%$ of the farmers and their assessment, the rice yield has been increasing when compared to past 5 years, while all the farmers of group 1 and 5 reported the yield of rice having increased. The main reasons that contributed to the increase in the rice yield are mainly adoption of modern high yielding varieties, better farm management techniques, use of chemical fertilizer, and good investment made for water control and irrigation facilities. On the other hand about $25 \%$ of the farmers responded of rice

Table 19. Yield of rice by group and season (Unit: ton/ha)

\begin{tabular}{lcccccc}
\hline \multicolumn{1}{c}{ Indicator } & Group 1 & Group 2 & Group 3 & Group 4 & Group 5 & Average \\
\hline Winter-Spring & 5.86 & 5.94 & 6.08 & 6.37 & 6.33 & 6.11 \\
Summer-Autumn & 4.33 & 4.12 & 4.39 & 4.33 & 4.50 & 4.31 \\
Spring-Summer & 4.00 & 3.76 & 3.97 & 4.03 & 4.50 & 3.96 \\
\hline
\end{tabular}

Source: survey 2002

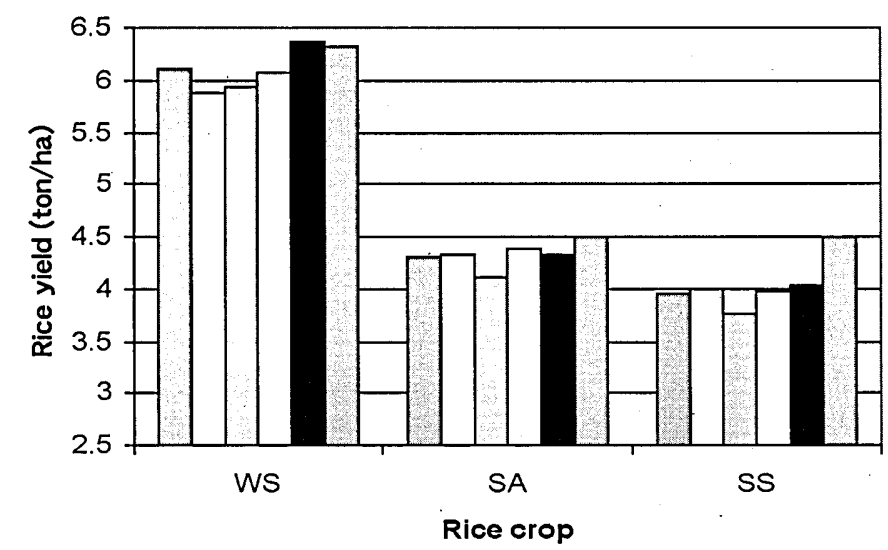

口 Average $\square$ Group $1 \square$ Group 2 a Group 3 Group 4 a Group 5

Figure 4. Rice yield by group and season 
yield remaining almost same for the last 5 years.

\section{Cost and economic profitability}

The costs of rice production are calculated for each crop. Total cost of production per hectare, including family labor cost, are 4,319.36, 4,488.86 and 4,380.31 thousand VND in 3 seasons of winter-spring, summer-autumn and spring-summer, respectively as seen in the Tables 20,21 and 22. In general, the total costs are not very much different across the seasons. The total cost in summer-autumn is higher compared to other seasons since harvesting activities occur in the beginning of flood season, hence it requires more labors for harvesting and sometime farmers should spend more for hired machine for rice drying. However, total costs are slightly different among groups. Total cost per one hectare of groups of farms with larger size (group 4 and 5) are found a little lower than those in small size groups. This may be evidence of a return to scale in rice production in the Mekong Delta. The reason of lower cost in larger farms could be explained that they require large amount of material inputs such as fertilizer, seeds, and other inputs, and so they are given offers of lower prices from sale agencies. Moreover, households with a large farm size are mainly wealthy households. They could buy fertilizers and store them in the house at the beginning of season when the prices of material inputs are still at low and stable level. While farms with small size due to lacking of capital cannot do so and finally they have to buy fertilizers and other inputs at the higher prices, and consequently leads to higher total cost. However, the differences of input prices are not significant due to the narrowness of rural market. The main cost saving advantage is

Table 20. Cost per one hectare of paddy in winter-spring season by groups (Unit: 1000 VND)

\begin{tabular}{lcccccc}
\hline \multicolumn{1}{c}{ Item } & Average & Group 1 & Group 2 & Group 3 & Group 4 & Group 5 \\
\hline Total cost & 4319.36 & 4381.09 & 4452.32 & 4369.77 & 4041.28 & 4222.79 \\
1 Material cost & 2568.63 & 2566.13 & 2645.08 & 2586.05 & 2396.92 & 2615.19 \\
Seed & 408.07 & 416.25 & 404.22 & 416.11 & 391.19 & 408.93 \\
Fertilizer & 968.13 & 949.27 & 1005.98 & 967.034 & 887.59 & 1037.41 \\
Pesticide & 332.71 & 242.35 & 395.22 & 300.3 & 338.09 & 378.87 \\
Herbicide & 139.26 & 94.33 & 119.8 & 132.83 & 166.75 & 208.85 \\
Hired machine & 583.20 & 683.33 & 579.85 & 635.28 & 487.79 & 463.13 \\
Fuel & 55.17 & 60.6 & 58.5 & 62.7 & 43.5 & 33.6 \\
Other material cost & 131.2 & 120 & 140 & 134.5 & 125.5 & 118 \\
2 Labor cost & 1443.7 & 1523.96 & 1504.24 & 1483.22 & 1330.56 & 1261.9 \\
Family & 1101.19 & 1523.96 & 1425.64 & 1106.1 & 663.66 & 614.5 \\
Hired labor & 342.52 & 0 & 78.6 & 377.115 & 666.9 & 647.4 \\
3 Other cost & 307.02 & 291 & 303 & 300.5 & 313.8 & 345.7 \\
Paying interest of borrowings & 34.13 & 15.5 & 25.5 & 32.5 & 48.5 & 55.3 \\
Land use tax & 231.66 & 245.5 & 237.5 & 224.5 & 222.7 & 245.7 \\
Others & 41.24 & 30 & 40 & .43 .5 & 42.6 & 44.7 \\
Unit cost (VND/kg) & 698.22 & 787.97 & 749.55 & 718.71 & 588.25 & 636.92 \\
Output value per hectare & 9033.47 & 7228 & 8316 & 8816 & 10854.6 & 10608 \\
Estimated profit & 4714.12 & 2846.91 & 3663.68 & 4446.23 & 6813.32 & 6385.21 \\
Family income & 5815.3 & 4370.87 & 5289.32 & 5552.33 & 7476.98 & 6999.71 \\
\hline
\end{tabular}

Source: survey 2002 
Table 21. Cost per one hectare of paddy in summer-autumn season by groups (Unit: 1000VND)

\begin{tabular}{lcccccc}
\hline \multicolumn{1}{c}{ Item } & Average & Group 1 & Group 2 & Group 3 & Group 4 & Group 5 \\
\hline Total & 4488.864 & 4617.09 & 4740.82 & 4462.47 & 4198.78 & 4337.39 \\
1 Material cost & 2640.84 & 2636.13 & 2733.58 & 2678.75 & 2430.42 & 2639.79 \\
Seed & 402.424 & 396.25 & 404.225 & 416.108 & 381.194 & 389.93 \\
Fertilizer & 982.631 & 1009.27 & 1005.98 & 987.034 & 887.599 & 1047.41 \\
Pesticide & 332.705 & 242.35 & 395.22 & 300.3 & 338.09 & 378.87 \\
Herbicide & 139.261 & 94.33 & 119.8 & 132.83 & 166.75 & 208.85 \\
Hired machine & 590.452 & 693.33 & 589.85 & 645.28 & 487.79 & 463.13 \\
Fuel & 62.17 & 80.6 & 78.5 & 62.7 & 43.5 & 33.6 \\
Other material cost & 131.2 & 120 & 140 & 134.5 & 125.5 & 118 \\
2 Labor cost & 1541 & 1690 & 1704.2 & 1483.2 & 1454.6 & 1351.9 \\
Family & 1167.78 & 1689.96 & 1625.64 & 1106.1 & 663.66 & 614.5 \\
Hired labor & 373.216 & 0 & 78.6 & 377.115 & 790.9 & 737.4 \\
3 Other cost & 307.023 & 291 & 303 & 300.5 & 313.8 & 345.7 \\
Paying interest of borrowing & 34.13 & 15.5 & 25.5 & 32.5 & 48.5 & 55.3 \\
Land use tax & 231.655 & 245.5 & 237.5 & 224.5 & 222.7 & 245.7 \\
Others & 41.2375 & 30 & 40 & 43.5 & 42.6 & 44.7 \\
Unit cost (VND/kg) & 1023.22 & 1066.3 & 1150.68 & 1016.51 & 887.692 & 963.8643 \\
Output value per ha & 6426.96 & 5629 & 5562 & 6409.4 & 7568 & 7650 \\
Estimated profit & 1938.09 & 1011.91 & 821.182 & 1946.93 & 3369.22 & 3312.611 \\
Family income & 3105.87 & 2701.87 & 2446.82 & 3053.03 & 4032.88 & 3927.111 \\
\hline
\end{tabular}

Source: survey 2002

in labor cost and hired machine cost saving due to large farm's investment in machinery such as tractor, threshing machine, and so on.

In the total cost, the material costs occupy high proportion (57-63\%), and this indicate that the rice grower mostly depends on resource from outside of farming; hence the market factor plays a very important role, and effects on rice production. Regarding to material costs, expenses for some inputs also hold high proportion, such as fertilizer accounting to $30-40 \%$ of total material cost, hired machine $15-26 \%$, seed cost $11-17 \%$, and pesticide $9-12 \%$. Therefore, the fluctuation of input prices, especially fertilizer prices and machine service charges has a big impact on unit cost of rice production.

Profits (calculated by Output value-Total cost) regarding to different crops and farm groups are also calculated. As seen in the tables, profit has large variation across seasons and groups attaining the highest value of 4714.12 thousand VND in winter-spring season, if we include family labor cost this figure turns to be indicator of family income (or return to labor and land) and reaches to 5815.3 thousand VND, meanwhile those figures are 1938.09 thousand and 3105.87 thousand VND in summer-autumn season and 1804.3 thousand and 2905.48 thousand VND in spring-summer season, respectively. Indicators of profit and family income are also varied by groups of farmers. According to the result of analysis, group 4 (with size of 1-3 hectare) has the highest profit and income per hectare from rice production.

Unit cost is found the lowest in winter-spring season ranging from 588.25 to 787.95 VND per one $k g$ with average of $698.22 \mathrm{VND} / \mathrm{kg}$, then followed by summer-autumn with average unit cost of $1150.68 \mathrm{VND} / \mathrm{kg}$ and spring-summer crop has highest unit cost with 
Table 22. Cost per one hectare of paddy in spring-summer season by groups (Unit: 1000 VND)

\begin{tabular}{lcccccc}
\hline \multicolumn{1}{c}{ Item } & Average & Group 1 & Group 2 & Group 3 & Group 4 & Group 5 \\
\hline Total & 4380.31 & 4353.09 & 4509.82 & 4462.47 & 4138.78 & 4198.39 \\
1 Material cost & 2629.59 & 2538.13 & 2702.58 & 2678.75 & 2494.42 & 2590.79 \\
Seed & 399.924 & 388.25 & 398.225 & 406.108 & 395.194 & 400.93 \\
Fertilizer & 953.131 & 849.267 & 1005.98 & 967.034 & 887.599 & 987.4095 \\
Pesticide & 367.71 & 342.35 & 400.22 & 340.3 & 388.09 & 378.87 \\
Herbicide & 139.261 & 94.33 & 119.8 & 132.83 & 166.75 & 208.85 \\
Hired machine & 583.202 & 683.33 & 579.85 & 635.28 & 487.79 & 463.13 \\
Fucl & 55.17 & 60.6 & 58.5 & 62.7 & 43.5 & 33.6 \\
Other material cost & 131.2 & 120 & 140 & 134.5 & 125.5 & 118 \\
2 Labor cost & 1443.7 & 1524 & 1504.2 & 1483.2 & 1330.6 & 1261.9 \\
Family & 1101.18 & 1523.96 & 1425.64 & 1106.1 & 663.66 & 614.5 \\
Hired labor & 342.516 & 0 & 78.6 & 377.115 & 666.9 & 647.4 \\
3 Other cost & 307.023 & 291 & 303 & 300.5 & 313.8 & 345.7 \\
Paying interest of borrowing & 34.13 & 15.5 & 25.5 & 32.5 & 48.5 & 55.3 \\
Land use tax & 231.655 & 245.5 & 237.5 & 224.5 & 222.7 & 245.7 \\
Others & 41.2375 & 30 & 40 & 43.5 & 42.6 & 44.7 \\
Unit cost (VND/kg) & 1071.24 & 1088.27 & 1199.42 & 1124.05 & 893.9 & 932.98 \\
Output value per ha & 6184.61 & 5600 & 5640 & 5756.5 & 7639.5 & 7425 \\
Estimated profit & 1804.3 & 1246.91 & 1130.18 & 1294.03 & 3500.72 & 3226.61 \\
Family income & 2905.48 & 2770.87 & 2555.82 & 2400.13 & 4164.38 & 3841.11 \\
\hline
\end{tabular}

Source: survey 2002

average of $1071.25 \mathrm{VND} / \mathrm{kg}$. Low unit cost in winter-spring season compared to other seasons indicates the high comparative advantage of winter-spring crop. Unit costs of farms with large size are also found lower than farms with small size. Besides the lower total cost per hectare of large size farms, other important factor which leads to lower unit cost of those farms is that higher yields are attainted in those farms.

\section{TECHNICAL EFFICIENCY AND PRODUCTIVITY OF RICE PRODUCERS IN THE MEKONG DELTA}

As described in detail in the section of Methodology, the stochastic production function has the disturbance term $\varepsilon$ which is composed of two parts, a systematic (V) and one-sided (U) components. In this paper a Cobb-Douglas production function of the following form was specified:

$$
\begin{aligned}
\operatorname{Ln} Y_{i} & =\beta_{0}+\beta_{1} \ln X_{1 i}+\beta_{2} \ln X_{2 i}+\beta_{3} \ln X_{3 i}+\beta_{4} \operatorname{Ln} X_{4 i}+\beta_{5} \ln X_{5 i}+\beta_{6} \ln X_{6 i}+\beta_{7} \ln X_{7 i} \\
& +\beta_{8} \ln X_{8 i}+V_{i}-U_{i}
\end{aligned}
$$

Where the subscript $\mathrm{i}$ indicates the $\mathrm{i}$-th farmer in the sample.

The $V_{i} s$ are random error that are assumed to be independently and identically distributed as $\mathrm{N}\left(0, \sigma_{\mathrm{v}}{ }^{2}\right)$

The $U_{i} s$ are non-negative technical inefficiency effects that are assumed to be independently distributed among themselves and the $V_{i} s$, such as $U_{i}$ is obtained by the truncation (at zero) of the normal distribution with mean $\mu_{i}$, and variance, $\sigma_{u}^{2}$, where $\mu_{i}$ is 
defined by:

$$
\mu_{i}=\delta_{0}+\delta_{1} Z_{1 i}+\delta_{2} Z_{2 i}+\delta_{3} Z_{3 i}+\delta_{4} Z_{4 i}+\delta_{5} Z_{5 i}+\delta_{6} Z_{6 i}+\delta_{7} Z_{7 i}+\delta_{8} Z_{8 i}
$$

Let $\sigma^{2}{ }_{u}$ and $\sigma^{2}{ }_{v}$ be the variance of one-sided $(\mathrm{u})$ and systematic (v), disturbance component. Therefore $\sigma^{2}=\sigma^{2}{ }_{u}+\sigma^{2}{ }_{v}$. is defined as the total variation of output from the frontier which can be attributed to technical efficiency. And the ratio of the two standard deviation are calculated as $\lambda=\sigma_{u} / \sigma_{v}$ or $\gamma=\sigma_{u}{ }_{u} /\left(\sigma_{u}{ }_{u}+\sigma^{2}{ }_{v}\right)$. The maximum likelihood estimates of the parameters of the above stochastic frontier model, computed using the program FRONTIER 4.1 (Coelli, 1996) is presented in Table 23.

This estimation is based on strict assumptions, and the sample data used for the estimation is not so large and cover only limited region. We should pay full attention to this point carefully when we give some interpretation to the results of estimation. The following interpretation will be given to the results of estimation assuming that the results

Table 23. Maximum likelihood estimates of the stochastic frontier production function

\begin{tabular}{|c|c|c|c|c|}
\hline \multirow{2}{*}{ Variable } & \multirow{2}{*}{ Parameters } & \multicolumn{3}{|c|}{ Season } \\
\hline & & Winter-spring & Spring-summer & Summer-autumn \\
\hline \multicolumn{5}{|l|}{ Stochastic frontier } \\
\hline Constant & $\beta_{0}$ & $8.43(21.26)^{* * *}$ & $7.73(4.93)^{* * *}$ & $7.93(11.7)^{* * *}$ \\
\hline Seeds $\left(\mathrm{X}_{1}\right)$ & $\beta_{1}$ & $-0.07(-2.32)^{* *}$ & $0.11(1.45)$ & $0.13(1.35)$ \\
\hline Nitrogen $\left(\mathrm{X}_{2}\right)$ & $\beta_{2}$ & $-0.05(-2.23)^{* *}$ & $-0.04(-3.12)^{* * *}$ & $0.03(1.17)$ \\
\hline Phosphate $\left(\mathrm{X}_{3}\right)$ & $\beta_{3}$ & $0.04(2.14)^{* *}$ & $0.06(4.56) * * *$ & $0.02(1.52)^{*}$ \\
\hline Potassium $\left(\mathrm{X}_{4}\right)$ & $\beta_{4}$ & $0.07(1.95)^{* *}$ & $0.1(2.12)^{* *}$ & $0.02(1.98)^{* *}$ \\
\hline Pesticide $\left(\mathrm{X}_{5}\right)$ & $\beta_{5}$ & $-0.02(-2.23)^{* *}$ & $-0.08(-1.78)^{* *}$ & $-0.01(-0.27)$ \\
\hline Labor $\left(\mathrm{X}_{6}\right)$ & $\beta_{6}$ & $0.05(0.89)$ & $0.21(1.55)^{*}$ & $-0.97(-1.27)$ \\
\hline Hired machine $\left(X_{7}\right)$ & $\beta_{7}$ & $0.07(1.05)$ & $0.12(1.24)$ & $0.1(3.51)^{* * *}$ \\
\hline Farm size $\left(\mathrm{X}_{8}\right)$ & $\beta_{8}$ & $0.0012(1.2)$ & $0.0008(0.12)$ & $0.007(0.8)$ \\
\hline \multicolumn{5}{|l|}{ Inefficiency model } \\
\hline Constant & $\delta_{0}$ & $0.29(2.9)^{* * *}$ & $1.45(12.3)^{* * *}$ & $0.23(18.18)^{* * *}$ \\
\hline Land dummy $\left(\mathrm{Z}_{1}\right)$ & $\delta_{1}$ & $-0.1(1.41)$ & $0.09(1.44)$ & $-0.14(-1.18)$ \\
\hline Land dummy $\left(\mathrm{Z}_{2}\right)$ & $\delta_{2}$ & $-0.7(-1.85)^{* *}$ & $0.11(1.11)$ & $-0.12(-2.53)^{* * *}$ \\
\hline Variety dummy $\left(\mathrm{Z}_{3}\right)$ & $\delta_{3}$ & $-0.1(-2.31)^{* * *}$ & $0.04(1.35)$ & $0.03(1.25)$ \\
\hline IPM adoption $\left(\mathrm{Z}_{4}\right)$ & $\delta_{4}$ & $-0.12(-2.24)^{* *}$ & $-0.07(2.05)^{* *}$ & $-0.09(-3.08)^{* * *}$ \\
\hline Sowing technique $\left(\mathrm{Z}_{5}\right)$ & $\delta_{5}$ & $-0.11(-1.98)^{* *}$ & $0.06(1.05)$ & $-0.026(-0.87)$ \\
\hline Education level $\left(\mathrm{Z}_{6}\right)$ & $\delta_{6}$ & $0.01(0.34)$ & $0.03(0.69)$ & $0.01(0.45)$ \\
\hline Marker access $\left(Z_{7}\right)$ & $\delta_{7}$ & $0.02(0.42)$ & $0.03(0.46)$ & $0.45(0.8)$ \\
\hline Credit availability $\left(\mathrm{Z}_{8}\right)$ & $\delta_{8}$ & $-0.15(-1.72)^{*}$ & $-0.19(-1.8)^{*}$ & $-0.21(-1.78)^{*}$ \\
\hline \multicolumn{5}{|l|}{ Variance parameters } \\
\hline$\sigma^{2}=\sigma^{2}+\sigma^{2}{ }_{v}$ & $\sigma$ & $0.018(3.17)^{* * *}$ & $0.003(7.21)^{* * *}$ & $0.001(9.57)^{* * *}$ \\
\hline$\gamma=\sigma^{2}{ }_{u} /\left(\sigma_{u}^{2}+\sigma_{v}^{2}\right)$ & $\gamma$ & $0.968(67.91)^{* * *}$ & $0.935(68.75)^{* * *}$ & $0.999(126.96)^{* * *}$ \\
\hline \multicolumn{2}{|c|}{ Mean technical efficiency } & 0.862 & 0.796 & 0.802 \\
\hline \multicolumn{2}{|l|}{ Maximum } & 0.987 & 0.937 & 0.957 \\
\hline \multicolumn{2}{|l|}{ Minimum } & 0.669 & 0.515 & 0.545 \\
\hline
\end{tabular}

Figures in parentheses are the $t$ statistics of model estimation

* Significant at $10 \%,{ }^{* *}$ significant at $5 \%$ and $* * *$ significant at $1 \%$. 
reflect the real effects correctly.

Consider the $\gamma$ parameters associated with the variance of the technical inefficiency effects in the stochastic frontiers in the tables 23 regarding 3 seasons; they are significantly different from zero. These imply that technical inefficiency in the production frontiers for paddy in three seasons do exist. The average technical efficiency for the sample are $86.23 \%, 79.55 \%$ and $80.24 \%$ with minimum of $66.9 \%, 51.5 \%$ and $54.5 \%$ for winter-spring, spring-summer and summer-autumn, respectively. Those imply that on the average the farmers are able to obtain $86.2 \%, 79.6 \%$ and $80.2 \%$ of potential output from a given mix of production inputs. Thus, in the short run, there is scope for increasing rice production by $13.8 \%, 20.45 \%$ and $19.76 \%$ across seasons respectively by adopting the technology and techniques used by the best practice paddy farms. The highest mean technical efficiency is found in the winter-spring, followed by summer-autumn, and last by spring-summer. The availability of water supply and favor weather condition and land silt accumulated after flood season of winter-spring may partly explain why rice producers operate more closely to best practice levels in this season than they do in other seasons.

The coefficient of seed sowing is negative in winter-spring and positive in other seasons. The reason for negative effects seed in winter-spring can be explained as follows. In winter-spring crop, farmers use new variety and adopt different techniques in sowing such as sowing by row, this method of sowing does not require much seed but still brings higher yield. However, magnitude of this parameter is not very large.

The elasticity coefficient of amount of active nitrogen is estimated to be negative highly significant. This implies that nitrogen is overused in rice production, now it is beyond the optimum level. Continuing usage of nitrogen could bring no benefit and could make the decreasing of rice yield in the future and moreover be harmful for soil and environment.

Coefficients of active phosphate and potassium use are both positive and statistically significant in 3 seasons. Those indicate that by applying more phosphate and potassium could bring higher paddy yield. However the magnitude of coefficient of phosphate is small in winter-spring season. Farmers in the Mekong Delta still apply at low level of potassium, therefore in order to increase yield, use of more fertilizer with high rate of potassium is strongly recommended.

Although the chemical fertilizer applied for rice in the Mekong Delta is quite high compared with other countries, it is unbalanced in ratio among the nitrogen, potassium and phosphate and consequently it not only affects the paddy yield, but also effects the environment and fertility of soil. Hence, the substitution of fertilizer with high nitrogen like urea by composite fertilizers NPK with proportionate ratio could help increasing paddy yield.

Coefficient of pesticide expense has unexpected sign in the winter-spring crop. This is due to the fact that, some households adopted IPM method and other methods in pest management and it could raise paddy yield but spend less cost for pesticide. Moreover, it is likely that pesticide could be overused.

Elasticity of labor for 2 seasons is estimated to be positive, and negative for other season, however all are not significant. This indicates that the use of labor reached to the frontier. Use of more labor could not bring higher yield anymore and the efficiency is low. 
Coefficient of expense for hired machine is positive and significant in summer-autumn at $1 \%$. This indicates that using machine for rice production could bring higher yield. That relates to better quality of land preparation and reduce the loss after harvest by using machines such as small tractor, threshing, cutting or drying machines. Using cutting and drying machines for rice production especially in summer-autumn is very necessary to reduce loss and increase rice quality. The result of estimation also shows the increasing demand of suitable and appropriate machine for rice production in the Mekong Delta. It also indicates that the level of mechanization in the Mekong Delta is higher than other regions in the country.

The coefficient of last variable of farm size in the stochastic function is positive and significant at $15 \%$ in winter-spring season. This indicates that increasing farm size could bring higher yield and larger farms seem to attain more technical efficiency than small farms do. However the magnitude of this coefficient is very small.

For the technical inefficiency effects, land size used in dummy variable is assumed to account for any difference in technical inefficiency that may arise from difference in scale of operation. Coefficients of land dummy variable $Z_{1}$ and $Z_{2}$ are both negative except spring-summer crop, but the coefficient of $Z_{l}$ is non significant, so the null hypothesis $\mathrm{H}_{0}$ stating that the difference of land holding size more than 3 ha with other sizes has no effect on the level of technical inefficiencies can not be rejected. The variable $Z_{2}$ with farm size between 1-3 ha is significant indicating that the farm size of 1-3 ha has effects on the level of technical inefficiency, and farmers who operate with farm size of 1-3ha could achieve highest efficiency. A negative relationship between technical inefficiency and land size implies that farmers with larger farms tend to be more efficient than farmers with small farms. Farmers on smaller farms could be less technically efficient because their land is fragmented, they have less access to public service, less timely to sufficient inputs of fertilizer, chemicals and irrigation, and they have less access to formal credit and other supportive programs. This is perhaps not surprising. As stated above, farmers with larger farms may encounter fewer problems than those with small farm in apply inputs at the right time and in the appropriate quantities, and they have advantages over small farm in investment of machine or other appliances or tools. The empirical evidence provides a justification, and in term of efficiency, land accumulation should be encouraged for land in rice production. However, the size of 1-3 hectare could be optimal solution in the short run. In addition, with the numerous small farmers and highly significant coefficient of land dummy, it could be inferred that it is possible to increase paddy yield by consolidating holding through cooperative effort.

Other coefficients of dummy variables of rice variety use, IPM adoption, and sowing technique are almost negative and significant as expected. However, the difference of paddy yield between the farmers who use new varieties, or adopt IPM program and sowing by row and farmers who does not adopt those techniques is only small since the impact of magnitude shown in coefficients are not high. This can be explained as follows. For rice varieties, the classification of "old" and "new" varieties is only by the time when the varieties are released, but both kinds of varieties are high yielding varieties according to the definition of IRRI. If condition of good care is realized the difference of yield between them is not very significant, but in the long run the "old" varieties could show the genetic degradation and it could effect on the yield. For the IPM adoption, although 
the increase of yield is very small, but the main benefit of IPM method is reducing cost of pesticide, creating better environment and farmers' health. Sowing by row helps reduce seeding rate, labor for caring and weeding, reduce pest and disease, hence indirectly affects on rice yield. So the IPM program and sowing by row could help farmers reduce the total cost and increase profit for the rice farm. Other things being equal, the adoption of new varieties, IPM program and new sowing technique should be encouraged in rice production. It not only brings higher yield but also reduces cost and creates sustainable, safety environment and stable yield for long run. Here the role of agricultural extension organization should be emphasized.

Further investigation was examined to understand why various programs such as IPM program or new techniques have adopted by small groups of farmers. It was found that extension workers and other program officials were hampered in their extension work by administrative burdens and lack of funds. This led to: 1) infrequent performance of demonstration plot experiments to aid the dissemination of new technology; 2) inadequacies in training and development of farmer groups and extension personnel; and 3) a low proportion of farmer groups are capable of carrying out the programs. Other problems likely to increase technical inefficiency have included the careless use of main technological inputs of seed, fertilizer, and a lack of access to timely credit caused by complex procedures for formulating and ratifying credit proposals. Ensuring the better access to credit of farmers and improving activities of agricultural extension organization could be important in promoting greater technical efficiency.

The dummy variable of level of education is used as a proxy for managerial input. It was expected that increased farming experience coupled with higher level of educational achievement would lead to better efficient use of inputs. The coefficient has positive sign not as expected, however it is not significant. This indicates that lower level of secondary education (4-5 year of schooling) does not have much effect on paddy productivity.

The last variable of availability of credit has negative and significant coefficient implying that the credit is also one of factor affecting to technical inefficiencies. Decreasing credit by $1 \%$ will decrease the farmer's technical efficiency by 0.15 percent in winter-spring crop. Therefore better access will significantly increase farmers' technical efficiency. Some progress was achieved in recently in the field of rural credit, but more improvements are still needed.

The frequency distribution of the efficiency estimates obtained from stochastic frontier model across seasons and farm size groups are presented in Table 24, Table 25 and Table 26. More than $25.84 \%, 5.8 \%$ and $5.8 \%$ of the sample farm operates with efficiency level greater than $90 \%$ in winter-spring, spring-summer and summer-autumn, respectively as can be seen from the tables.

For further illustration of the results, Figure 5 depicts the distribution of technical efficiencies of paddy across season.

In terms of absolute value of yield loss due to technical inefficiency of the farmers, the results show that the yield loss due to technical inefficiency varies from zero to more than $2000 \mathrm{~kg}$ per hectare. Average yield loss was higher in winter-spring than summer-autumn season. The average yield loss was $727.03 \mathrm{~kg}$ and $705.93 \mathrm{~kg}$ per hectare for the winter-spring and summer-autumn crops, respectively (Table 27). The results indicate relatively high yield loss per hectare due to technical inefficiency. 
Table 24. Frequency distribution of technical efficiency estimates from stochastic frontier model across farm size groups in winter-spring season (unit: \%)

\begin{tabular}{lcccccc}
\hline \multicolumn{1}{c}{ Efficiency score } & Group 1 & Group 2 & Group 3 & Group 4 & Group 5 & Total \\
\hline Less than 60 & 0 & 0 & 0 & 0 & 0 & 0 \\
$60-65$ & 0 & 3.33 & 0 & 0 & 0 & 0.83 \\
$65-70$ & 0 & 0 & 0 & 0 & 0 & 0 \\
$70-75$ & 8.33 & 3.33 & 4.44 & 0 & 0 & 3.33 \\
$75-80$ & 16.67 & 6.67 & 6.67 & 4.55 & 8.33 & 7.5 \\
$80-85$ & 25.0 & 30.0 & 26.67 & 18.18 & 25.0 & 25.83 \\
$85-90$ & 41.67 & 50.0 & 42.22 & 13.63 & 16.67 & 36.67 \\
$90-95$ & 8.33 & 6.67 & 17.78 & 45.45 & 41.67 & 21.67 \\
$95-100$ & 0 & 0 & 2.22 & 18.18 & 8.33 & 4.17 \\
Average mean efficiency & 0.841 & 0.845 & 0.856 & 0.904 & 0.877 & 0.862 \\
\hline
\end{tabular}

Source: calculation Note: ${ }^{1:}$ simple average of the total observation

Table 25. Frequency distribution of technical efficiency estimates from stochastic frontier model across size groups in spring-summer season (unit: \%)

\begin{tabular}{|c|c|c|c|c|c|c|}
\hline Efficiency score & Group 1 & Group 2 & Group 3 & Group 4 & Group 5 & Total \\
\hline Less than 60 & 8.33 & 3.33 & 0 & 0 & 0 & 1.67 \\
\hline $60-65$ & 8.33 & 0 & 0 & 0 & 0 & 0.83 \\
\hline $65-70$ & 8.33 & 6.67 & 0 & 0 & 0 & 2.5 \\
\hline $70-75$ & 16.67 & 36.67 & 26.27 & 9.09 & 8.33 & 23.33 \\
\hline $75-80$ & 25.0 & 20.0 & 6.67 & 18.18 & 25.0 & 15.83 \\
\hline $80-85$ & 16.67 & 20.0 & 40.0 & 36.36 & 50.0 & 33.33 \\
\hline $85-90$ & 8.33 & 13.33 & 20.0 & 22.72 & 8.33 & 16.67 \\
\hline $90-95$ & 8.33 & 0 & 2.22 & 4.55 & 8.33 & 3.33 \\
\hline $95-100$ & 0 & 0 & 4.44 & 9.09 & 0 & 2.5 \\
\hline Average mean efficiency ${ }^{1}$ & 0.738 & 0.760 & 0.808 & 0.830 & 0.820 & 0.796 \\
\hline
\end{tabular}

Source: calculation Note: : simple average of the total observation

Table 26. Frequency distribution of technical efficiency estimates from stochastic frontier model across size groups in summer-autumn season (unit:\%)

\begin{tabular}{lcccccc}
\hline Efficiency score & Group 1 & Group 2 & Group 3 & Group 4 & Group 5 & Total \\
\hline Less than 60 & 0 & 3.33 & 0 & 0 & 0 & 8.33 \\
$60-65$ & 8.33 & 3.33 & 0 & 0 & 0 & 1.67 \\
$65-70$ & 8.33 & 3.33 & 0 & 0 & 0 & 1.67 \\
$70-75$ & 8.33 & 36.67 & 26.67 & 9.09 & 0 & 21.67 \\
$75-80$ & 33.33 & 20.0 & 6.67 & 18.18 & 25.0 & 16.67 \\
$80-85$ & 16.67 & 16.67 & 40.0 & 27.27 & 50.0 & 30.83 \\
$85-90$ & 16.67 & 16.67 & 20.0 & 31.81 & 16.67 & 20.83 \\
90-95 & 8.33 & 0 & 2.22 & 4.55 & 8.33 & 3.33 \\
95-100 & 0 & 0 & 4.44 & 9.09 & 0 & 2.5 \\
Average mean efficiency & 0.793. & 0.757 & 0.803 & 0.841 & 0.835 & 0.802 \\
\hline
\end{tabular}

Source: calculation Note: ${ }^{1:}$ simple average of the total observation 


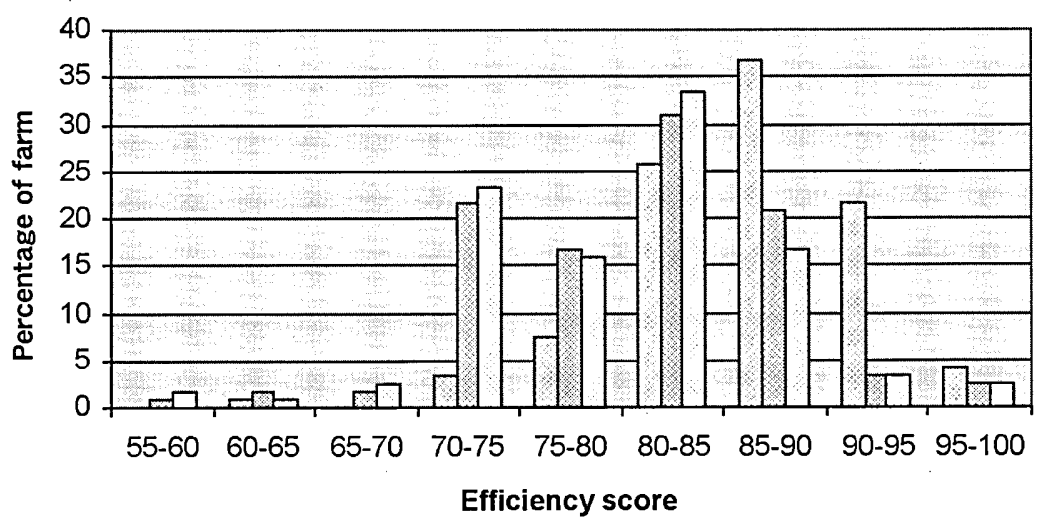

\section{$\square$ WS $\square S S \square S A$}

Figure 5. Distribution of technical efficiencies of seasons

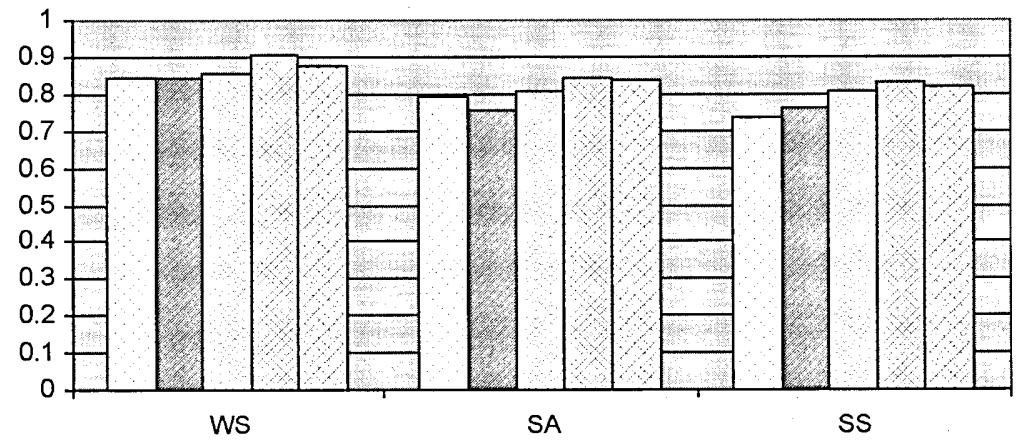

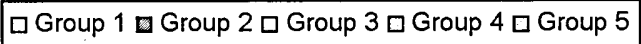

Figure 6. Mean efficiency by farm size groups

Table 27. Frequency distribution of yield loss due to technical inefficiency (unit: \%)

\begin{tabular}{ccccccccc}
\hline \multirow{2}{*}{$\begin{array}{c}\text { Range of yield loss } \\
\text { (kg/ha) }\end{array}$} & \multicolumn{9}{c}{ Group } & & \multicolumn{3}{c}{ Season } \\
\cline { 2 - 5 } & Group 1 & Group 2 & Group 3 & Group 4 & Group 5 & & WS & SA \\
\hline $0-500$ & 25.0 & 33.33 & 24.44 & 72.72 & 45.45 & & 37.5 & 35.0 \\
$501-1000$ & 58.33 & 40.0 & 42.22 & 22.72 & 45.45 & & 40.5 & 43.33 \\
$1001-15000$ & 0.0 & 26.67 & 31.11 & 4.54 & 9.09 & & 20.0 & 20.0 \\
$1500-2000$ & 8.33 & 0.0 & 2.22 & 0.0 & 0.0 & & 1.67 & 1.67 \\
$>2000$ & 8.33 & 0.0 & 0.0 & 0.0 & 0.0 & & 0.83 & 0.0 \\
Mean yield loss & 972 & 790 & 795 & 388 & 688 & & 727.03 & 705.93 \\
\hline
\end{tabular}

Source: Calculation 
The comparison among groups of farmers show that on average farmers of small size groups (group 1, 2 and 3) have had significantly higher yield loss due to technical inefficiency than larger size ones (group 4 and group 5). Besides the factors such as IPM method adoption, sowing technique, variety which contribute to the technical inefficiency, the results also imply that farmers with larger farm size especially farm size of 1-3 hectares has increased their technical efficiency among studied farmers.

Identification of specific factors that led to variation in the farm-specific technical efficiency is of profound relevance for formulating strategies necessary to narrow the prevailing gap and increase productivity. With the given database, this was imponderable. However, the resource use patterns of some of the most efficient (above $95 \%$ technical efficiency) farms were examined. It was then found that the most efficient farms practiced as follows: 1) employed 56 man-days of labor, 2) used $146 \mathrm{~kg}$ of seed, $85 \mathrm{~kg}$ of active nitrogen, $50 \mathrm{~kg}$ of phosphate and $25 \mathrm{~kg}$ potassium per hectare, 3) used new rice varieties, 4) adopted IPM method, 5) used technique of sowing by row and 6) operated in farm size of $1-3$ hectare, which resulted in the production of 7.1 and 5.5 ton of paddy per hectare in winter-spring and summer-autumn crop respectively.

\section{Optimization of input use and test for allocative efficiency}

As discussed in the section of methodology, technical efficiency evaluates the ability to obtain a higher level of output from a given set of inputs, while allocation efficiency measures the extent to which farmers make efficient decisions by using inputs up to level at which marginal contribution to production value equal to the factor cost. Here the marginal product of input $X_{i}\left(M P_{X i}\right)$, marginal value product $\left(M V P_{X i}\right)$, and ratio $M P V_{X i} / P_{X i}$ are calculated and depicted in the table 28.

Coefficients of seed quantity, of expense for pesticide, and of quantity of active nitrogen have all negative signs, suggested that those inputs are overused. They are allocatively inefficient, hence, reducing amount of those inputs will result in both increase of yield and reduce of cost of rice and it will bring higher profit for rice growers. Here $M V P_{X i}$ is used to test allocative efficiency for only 2 positive coefficients of active phosphate and potassium quantity. Two price used here are a given price at present ( $1500 \mathrm{VND}$ per kilogram) and an expected future price of rice (2000 VND per kilogram), then the ratios $r_{i}=$ $M V P_{X i} / P_{X i}$ are calculated. The results indicate that both inputs are now allocated ineffi-

Table 28. Test for $\mathrm{MVP}_{\mathrm{Xi}}$ of some inputs

\begin{tabular}{lcc}
\hline \multicolumn{1}{c}{ Descriptive } & Phosphate & Potassium \\
\hline Average marginal product $\left(\mathrm{MP}_{\mathrm{xi}}\right)$ & 6.48 & 32.87 \\
Marginal value product $\left(\mathrm{MVP} \mathrm{x}_{\mathrm{i}}\right)$ & 9723.185 & \\
Rice price of $1500 \mathrm{VND} / \mathrm{kg}$ & 12964.25 & 49301.83 \\
Rice price of $2000 \mathrm{VND} / \mathrm{kg}$ & & 65735.77 \\
\hline $\mathrm{r}_{\mathrm{i}}=\mathrm{MVP}_{\mathrm{xi}} / \mathrm{P}_{\mathrm{xi}}$ & 0.78 & \\
Rice price of $1500 \mathrm{VND} / \mathrm{kg}$ & 1.04 & 1.7 \\
Rice price of $2000 \mathrm{VND} / \mathrm{kg}$ & & 2.27 \\
\hline
\end{tabular}

Source: Calculation 
ciently because of having difference with 1 of both ratios with significant of $5 \%$. With the given paddy price at present of 1500 VND per kilogram, the ratios $r$ are 0.78 and 1.7 for phosphate and potassium variables, respectively. Those results suggest that in order to maximize profit farmers could be advised to use more potassium in their fields. However, with higher expected price of paddy, it is worth applying more both kinds of fertilizers because both ratios are greater than one.

\section{CONCLUSION AND RECOMMENDATION}

In summary, the hypothesis that there are no technical inefficiencies of rice production among farmers was rejected. This result suggests that inefficiencies are present in rice production for all seasons in the Mekong Delta. It also suggests that the traditional production function, with no technical inefficiency effect, is not an adequate presentation of the data if the strict assumptions are true. The analysis reveals that the rice farmers could get benefit through the use of best-practice production methods.

In the stochastic frontier production function, the explanatory variables-nitrogen active, phosphate active, potassium active, expense for hired machine-have significant effects to paddy productivity. And the recommendation of use of appropriate and proportional dosage of fertilizer could bring greater benefit for rice growers. The variables-land size, use of variety, IPM program participatory, new technique in sowing, poor credit access contribute significantly to explanation of the technical inefficiency effects. Of particular interest is the affect of land size on technical inefficiency. It was found that farmers with larger farm size are often more technically efficient than farmers with small farms, so the policy in land accumulation should be motivated. However with the existing technology, the farm size of 1-3 hectare attains highest technical efficiency. This is true only for rice growing sector of farm management. Here the whole structure of farm management is not considered. In the process of restructuring of agriculture in Vietnam in recent years farm management as a whole should be considered.

The results of the study indicate that the appropriate policies creating active/sound environment for land accumulation should be motivated for efficient rice production.. Land market should be activated by abolishing/losing many regulations. The technologies transferred to the farmers should be prioritized and focused on improving rice seed and varieties, technique of seeding by row, the IPM program, and post harvest technologies like drying and milling and processing. The extension services should be strengthened so as to enable the farmers to follow effective resource use pattern and practices to improve the efficiency of paddy farms. The rural credit system still needs to be improved especially in enhancing the access of small farmers to the credit facilities that would further help to increase the rice production in the Mekong Delta. The unbalanced application of nitrogen, phosphate and potash and overuse of pesticide not only affect the rice yield, but also creates some environmental and soil degradation problems. Although it is said that this problem is not so serious in paddy field as the case of upland field because every year the flood could help to cleanse the soil and silt could be accumulated, however, for the development of sustainable agriculture, the use of organic fertilizers and adoption of IPM method are recommended in order to improve the soil fertility, to create sound environment and for safe product. The development of the rural infrastructure is also considered 
as an important macro policy.

\section{REFERENCES}

Aigner, D., C. A. K. Lovell and P. Schmidt 1977 Formulation and Estimation of Stochastic Frontier Production Function Models. Journal of Econometrics 6: 21-37

Battese, G. E. and T. J. Coelli 1995 A Model for Technical Inefficiency Effects in a Stochastic Frontier Production Function for Panel Data. Empirical Economics 20: 325-332

Coelli, T. 1996 A Guide to FRONTIER Version 4.1: A Computer Program for Frontier Production Function Estimation. CEPA Working Paper 96/07, Department of Econometrics, University of New England, Armidale, Australia.

Farrell, M. J. 1957 The Measurement of Productive Efficiency. Journal of the Royal Statistical Society, 120: 252-90

Henderson, J. M. and R. E. Quandt 1980 Microeconomic Theory: A mathematical Aproach. $3^{\text {rd }}$ ed. Singapore. McGraw-Hill Book Company, Inc.

Kumbhaker, S. C. and Lovell C. A. K. 2000 Stochastic Frontier Analysis. Cambridge: Cambridge University Press.

Meeusen, W. and Van Den Broeck, J. 1977 Efficiency Estimation from Cobb-Douglas Production with Composed Error. International Economic Review, 18: 435-444 